\title{
Postoperative Surgical Complications
}

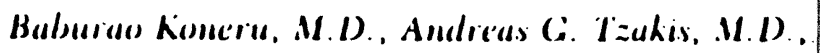 \\ James Boneman, III. M.D., Adrian (Cassucilla, M.D.. \\ Allbert B. Zajho, M.D., Thomus E. Starzl. M.D., Ph.D.
}

The ressults of liver tramsplantation have dramatically innproved since.

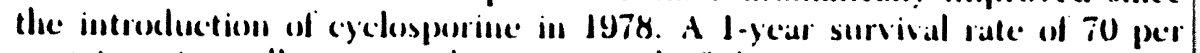
cent is universally expected now instead of the 30 per cont survival ritte secen consistently in the precegclosporine era.' Five-sear survival rate's of 5.5

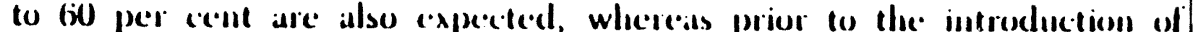
cyclosporime rate's were only is per cent." With this overall improvenent in survival, liver transplantation has become a widely alceepted form of therapy) for all endstage liver disc:ase and for somere forms of ancetabolic liver

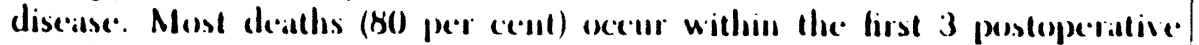

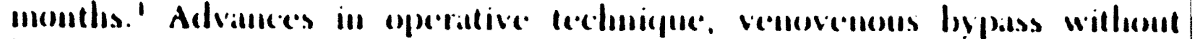

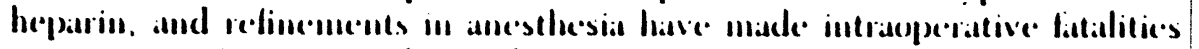
uncommons. However, the canly postoperatere course hollowing at liver

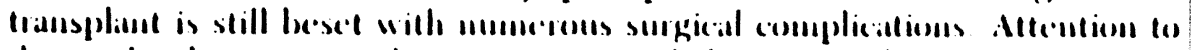
the early' detection and mantage'me'nt of these complications decreases morbidity and mortality. In thes anticle we will disconss the surgical (omupli-

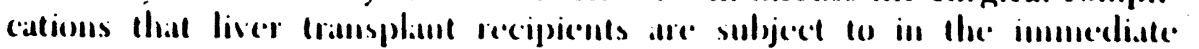
postoperative period. The following complications will be considered: intrat-

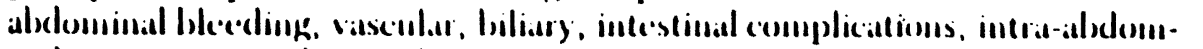
inal sepsis, wound complications, complications from liver biopss, and pallecreatitis.

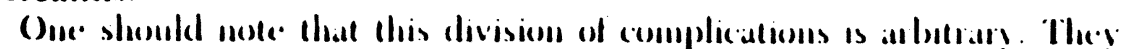

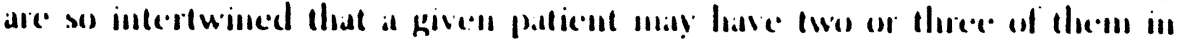

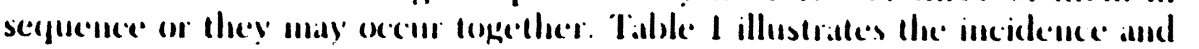
impertance of some of the se complications

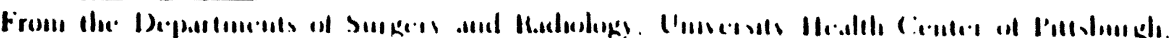

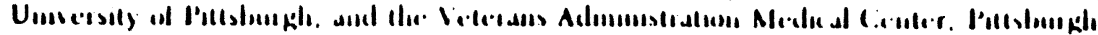

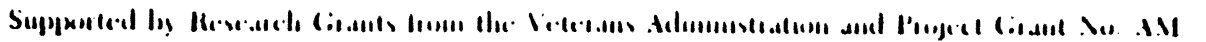

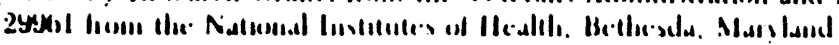




\section{INTHAABDOMINAL BLEEDING}

\section{Early Postoperative Bleeding}

Following liver transplant there is a high potential for postoperative bleeding. Numerous raw peritone:al surliaces and vascular andastomoses have been created. A well-functioning allograft with its synthesis of coagulation factors will take carce of the ovezing from most of these areas. Routincly three Jackson Pratt drains are inserted at the end of surgery to monitor the amount of postoperative diainage. Mlost of the drainage is serosanguinous ascitic fluid. A hematexrit of this fluid should be obtained if it appears excessively bloody, and it should be compared with the patient's hematex rit.

The highest risk of bleeding occurs within the hirst to hours following transplant. If the patient exhibits hemody'namic instability or recpuires five or more units of packed red cells (arbitrary) in 24 hours, re-exploration and control of bleeding is recommended. Whe'n postoperative bleeding occurs in a setting of marginal allogralt function, it is prudent to wait for 3 to 4 days to allow allograft function to innprove, if the patient can be maintained hemodynamically stable with tramsliusions. In uur program, in a 6-month period (Jantuary 1987-June 1987) 7 per cent of patients $(5.3$ per cent of transplants) recguired a reexploration for intrabibdominal bleceding (unpub)lished data).

At reexploration. Ilse bleeding could be from any of the vascular anastomoses, triangular ligament ancas, retroperitomeal areas behind the liver and drain site's, to name a lew possibilitie's. ()ccasionally the bleeding is from the allogialt (liver lacerations, gall bladder bed, and small branche's of the donor vesseds). Not uncommonnly, during exploration all that is found are large amounts of clots with no specilic bleeding source. If allogradt lunction is pexs, bleceling becomes a serions operative problem and prolungs the original surgery by several hours and, more freequently, necessitates reexploration in the early postenperative period. We have seen a lew patients develop) intriabdominal bleceding 3 or 4 day's after the transplant whe'n they have beell placeed on antiplatelet angents (Dextran, aspirin, and Dipyridamole).

In patients who have experienced aldedominal bleceding that has not been serious enough to recpuire explorition, an abdominal Cr scan is recommended to detect retained clots. If major clots are identitied, an operation to evaciate them is recommended to prevent secondary infection.

\section{Late Postoperative Bleeding}

In the late postoperative period, patients can develop aldedominal bleceding from a percutanesous liver biopsy and percutancous biliany tract procedures. Occasionally these recpuire lapparotomy to control the blecedinge (see under liver biopsy). In the presence of severe aldedominal sepsis, sudden massive intrabledominal bleceding (anl occur from distuption of inl arterial or portal anastomosis. (ontrol of these is extremely dillicult, oflen recquiring vascular grafting or vessel ligation. The prognosis in these cases is very pour. 


\section{DASCILAR COOMPLICATIONS}

urtal I cins

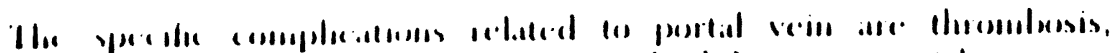

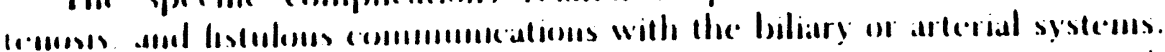

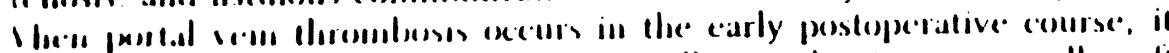

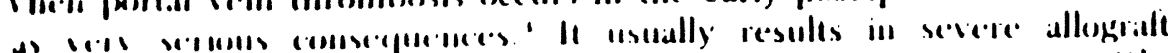

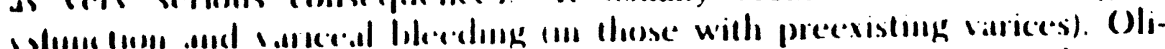

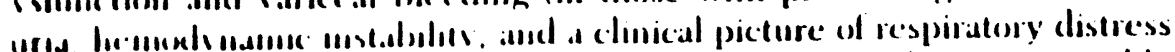

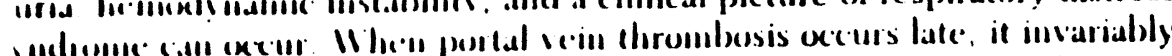

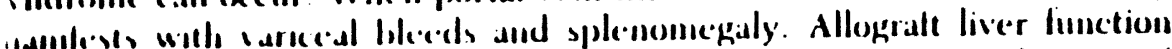

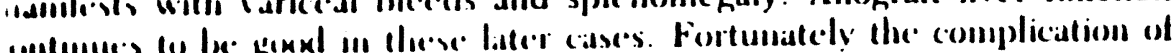

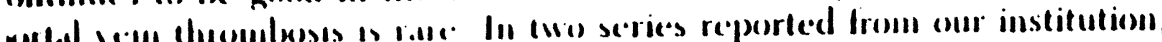

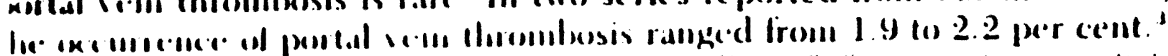

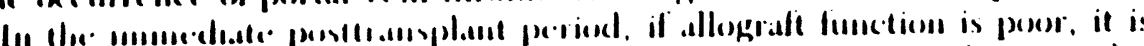

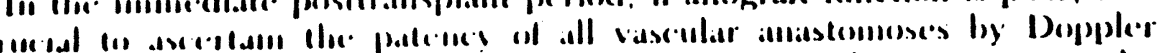

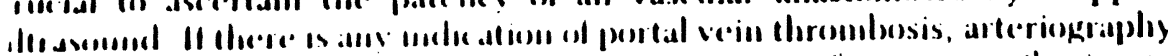

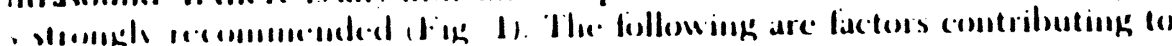

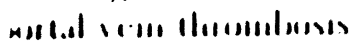

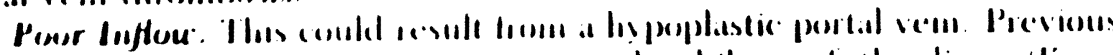

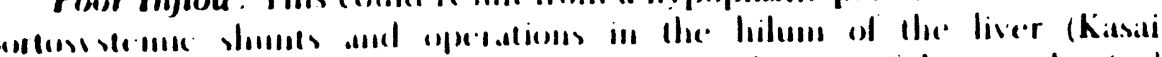

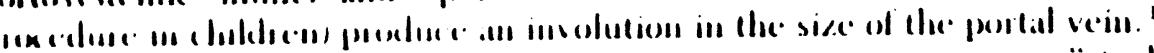

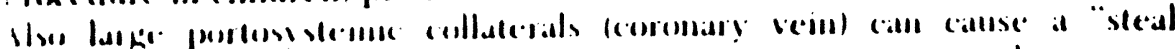

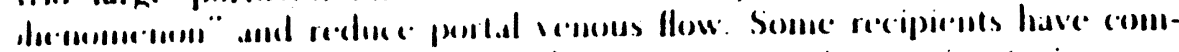

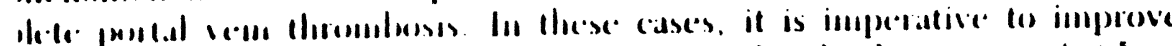

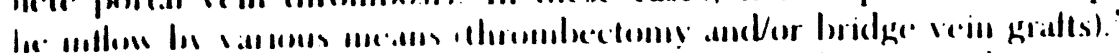

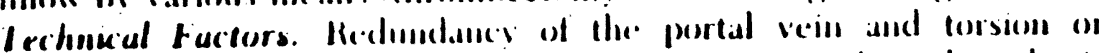

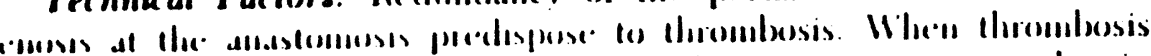

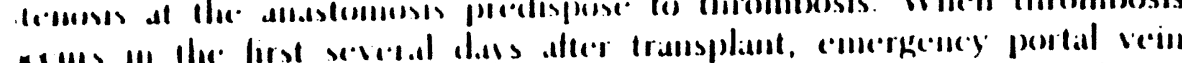

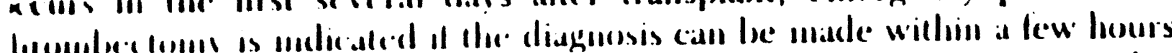

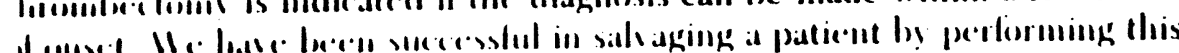

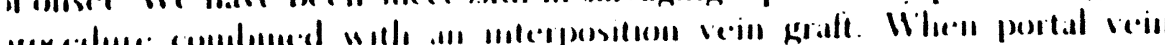

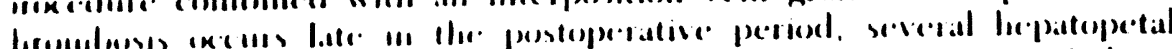

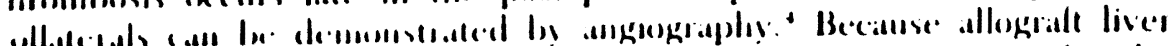

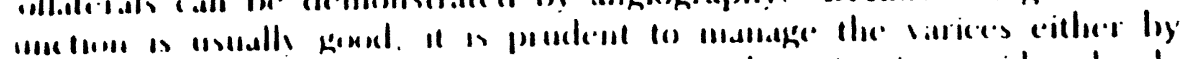

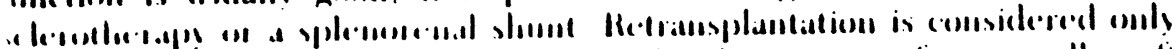

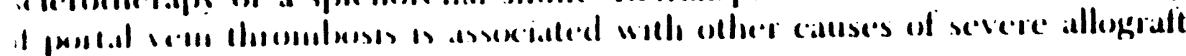

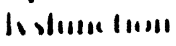

\section{Artcrial (implications}

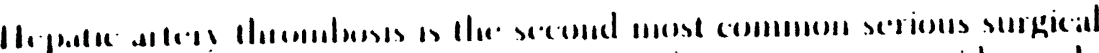

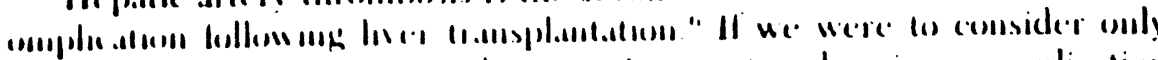

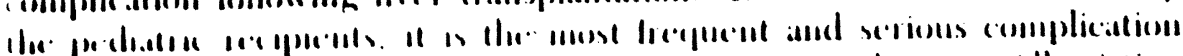

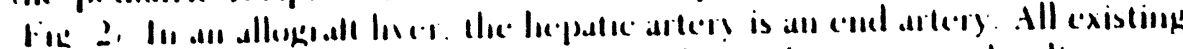

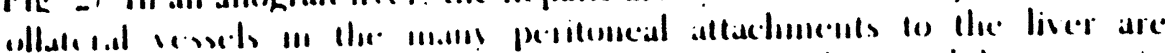

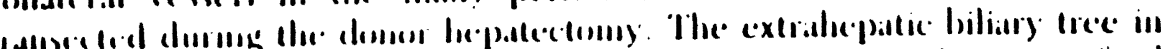

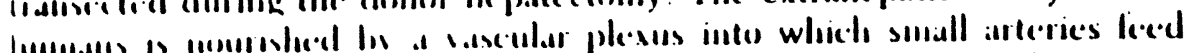

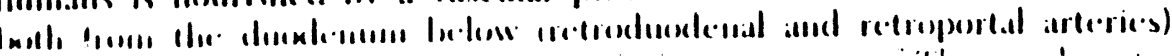

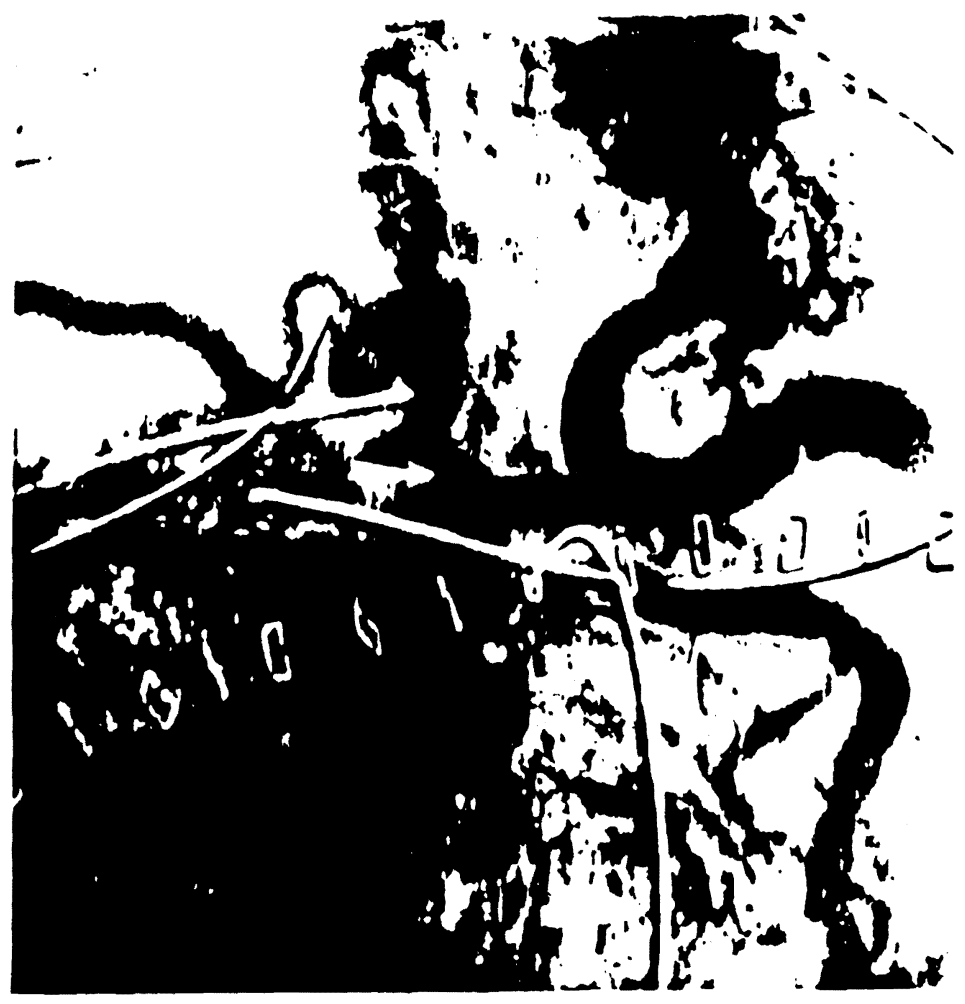

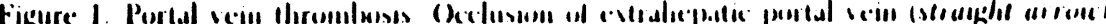

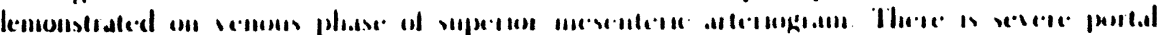

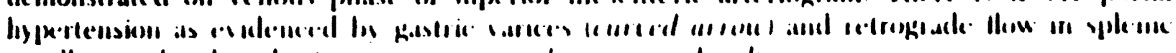

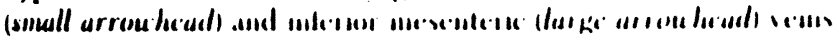

biliary tree is supplied by brancheses of the heppatic arteries. In the allogradt

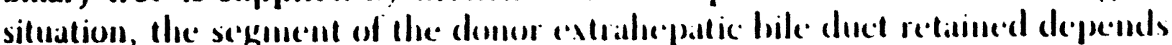

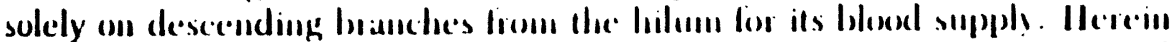

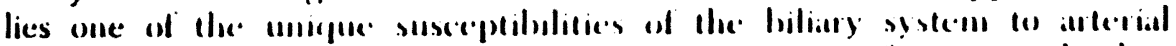

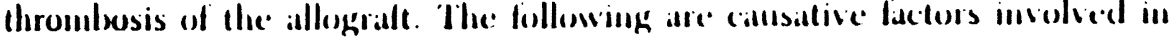
hepatic artery thrombosis

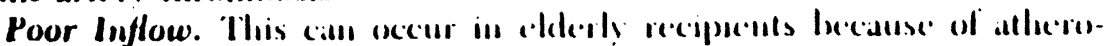

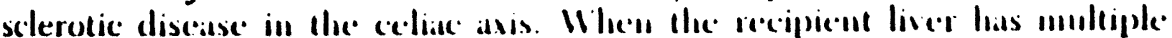
abersamt hepattic arteries, the coliac asis maty provide insullicient intlow. In

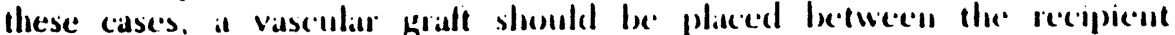

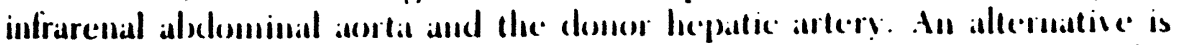

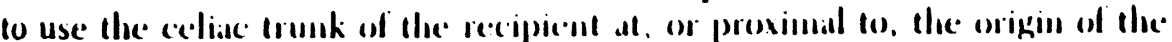

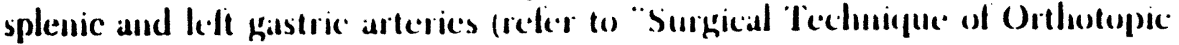
Liver Transplantiation").

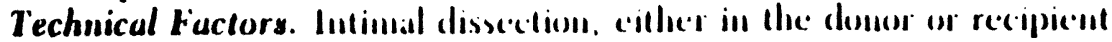

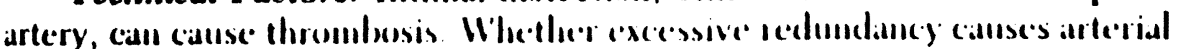

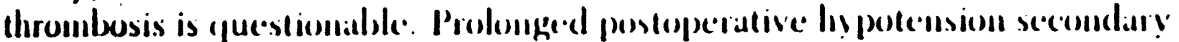
to sepsis or bleceding has cansed anterial thrombersis in a lew patients. The role of increased outllow resistance cantsed by a swollen liver secondare to

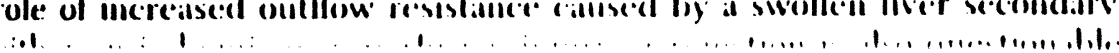




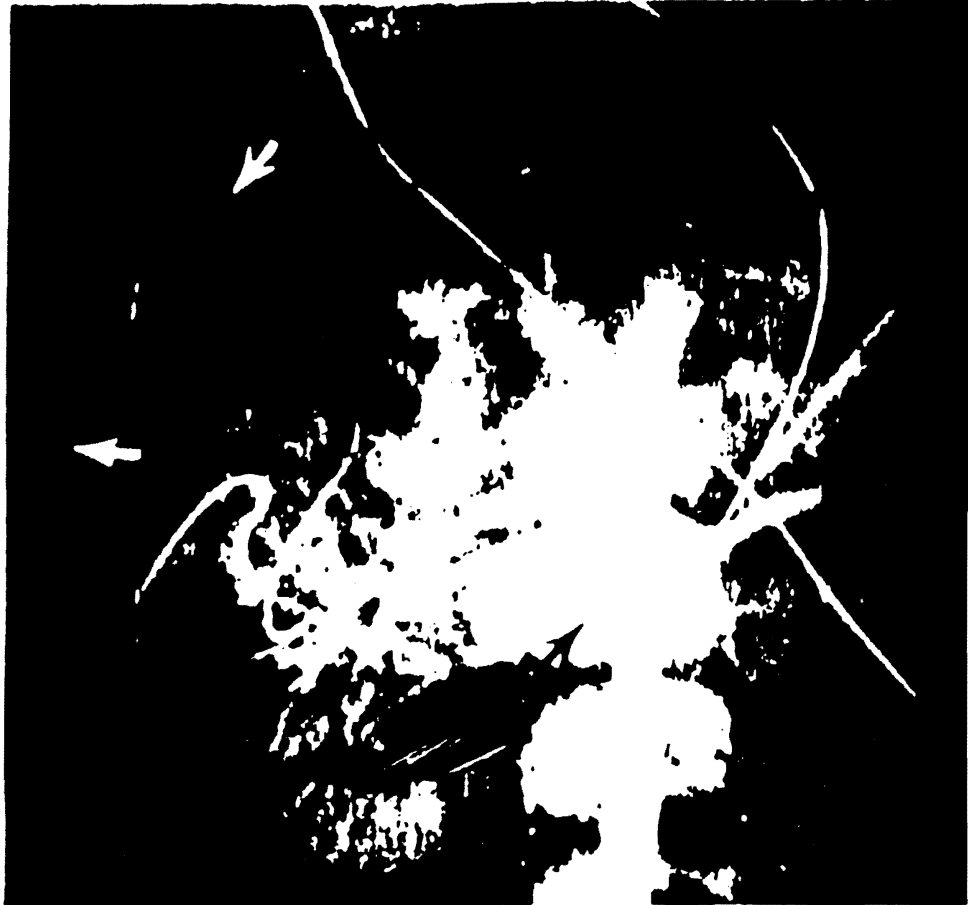

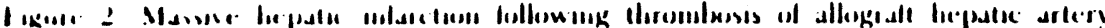

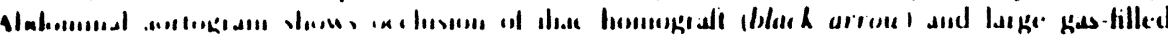

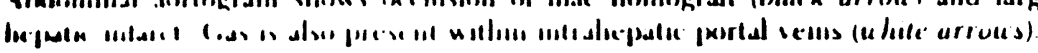

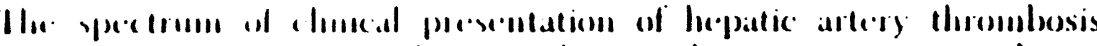

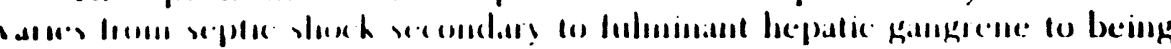

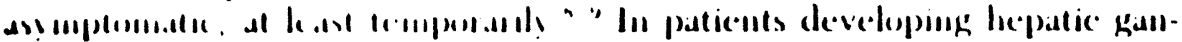

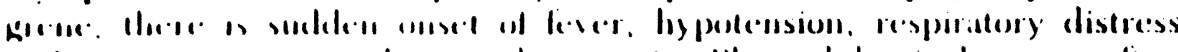

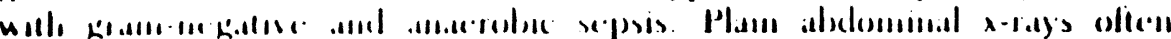

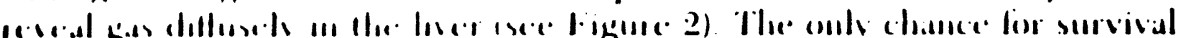

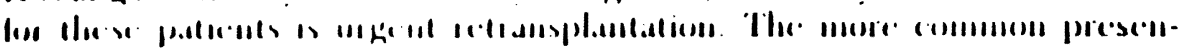

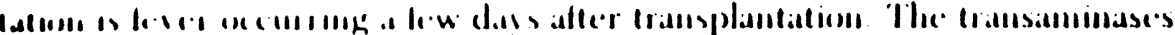

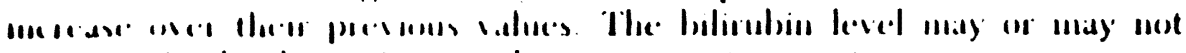

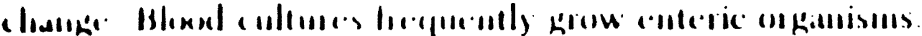

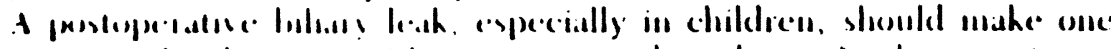

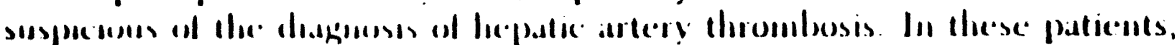

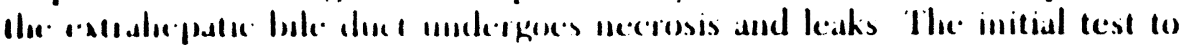

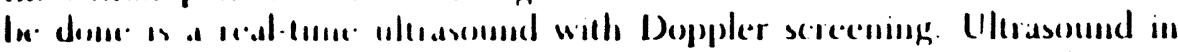

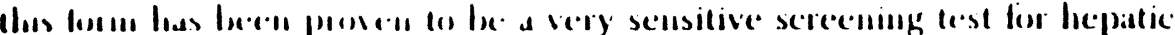

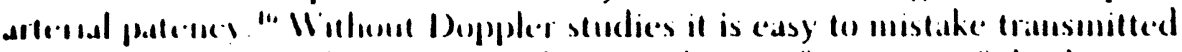

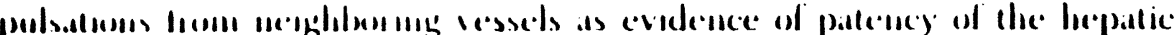

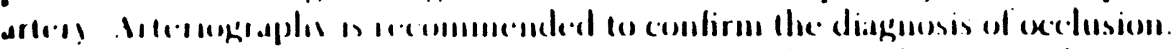

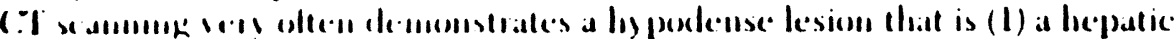

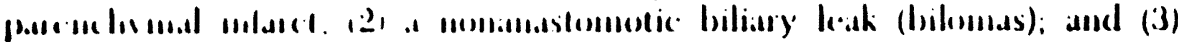

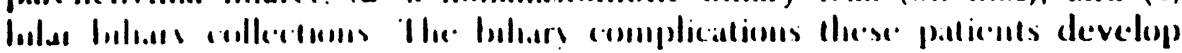

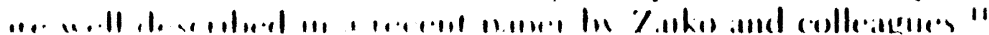

Managensent. Becallse of high incidence of sepsis with enteric ongall-

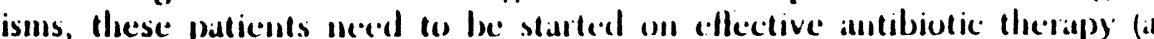
third-generation cephalosponin and anmpreillin is a good starting chosice). If the sepsis does mot respond in II) (1) If days, an attempt must be made to

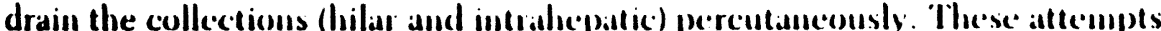
inay refuire placement of more than one callieter. Initially' the lluid drained is chocolate brown in color but frecpucontly it turns bilious in a lew days. Appropriate cultures of this fluid should be ubtained

Except in a sitnation of trank intraperententeal hiliary leak, restraint should be exercised in performinge ant aldelominal exploration in these patients because of the lisllowing: lhe liver is very triable; it is impossible to drain the multiple intrahephatic collections surgically; and the precarions

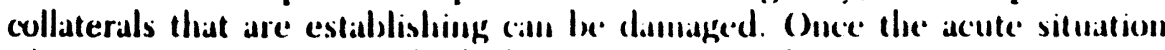
of systemic sepsis is controlled, these pottients face long-termin conse-puenters, which are multiple biliary structures trecpuently at the combluence of the ducts." They are often subject (1) recurrent eppisodes of cholangitis. We routinely place such paticents on long-term oral prophylactic bactrim therapy.

The indications for retransplantation ale the following: (1) accute linlminant hepatic gangrene; (2) inability to control systemic sepsis with parenteral antibiotics and percutaneons drainage; (3) recurrent episodes of cholangitis secondary (1) multiple biliany strictures. (Our ge'me'ral poslicy in these fiequently small patients (many of whom are less than $15 \mathrm{Kg}$ ) hads been to control the cholangitis with antibiotics and percutantevus drainage, if necessary, and allow them to grow; Heen consider retransplantation

The rare arterial complications of psendosnceurysms and arterioportal or arteriobiliary fistulate will not be discussed.

\section{Combined Portal and Arterial Thrombosis}

Fortumately combined portal and arterial thrombosis is rate. When it occurs, it does so within the first lew dats lesllowing transplantations. Pattients

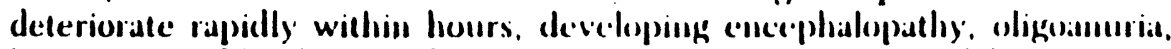

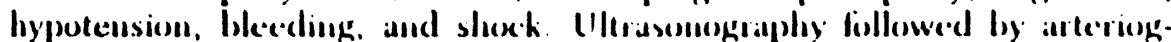

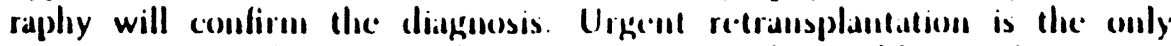
recourse: Even then survival is peses. We hate been able to salvage only one patient with this complication. The etiological lactors responsible for this combinced vascular complication are obscure. In one patient there was heavy deposition of immunoglolulin and complement in the vasculature. suggesting a possible immunological me'(hanism analogums to hipperacute rejection in renal transplants (unpulshlished data)

\section{Vena Cava Complicatious}

Stencosis or thrombesis of the inferion vella cava is an unusual compli-

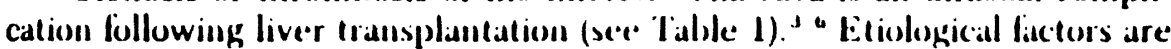
most likely to be techmical errors or recurtence of Budal-(hiari syindionte. Thrombosis of the vena cava has leeen secell in four piatients fome with a

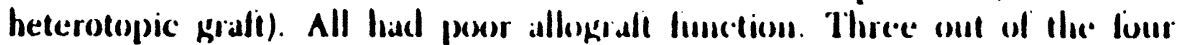

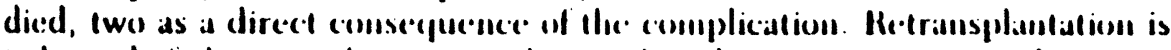




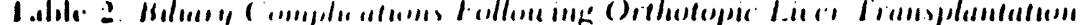

\begin{tabular}{|c|c|c|c|c|}
\hline ". & 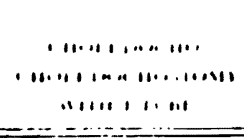 & 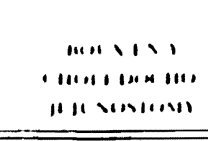 & 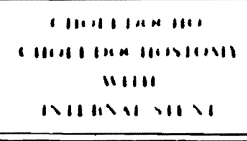 & 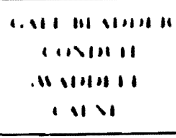 \\
\hline 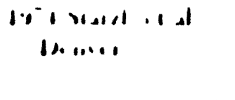 & י & & 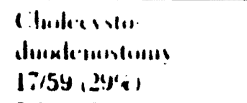 & \\
\hline 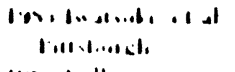 & 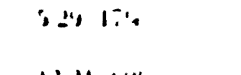 & 221,541 & $7 / 2.2(3224)$ & - \\
\hline 1…11. & $12: 1$ ixt? & $\cdots$ & $\cdots$ & $1: 2 \cdot 2.1,211 \cdot 61$ \\
\hline 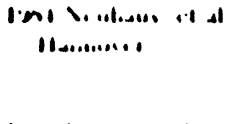 & I: sids. & $3(1,1-1 ; i)$ & 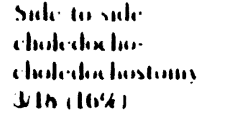 & \\
\hline 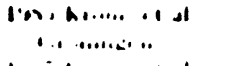 & $\because \therefore 1 \because$ & & & \\
\hline 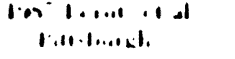 & 20101200 & 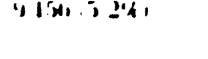 & $1+42(+3) 24)$ & - \\
\hline
\end{tabular}

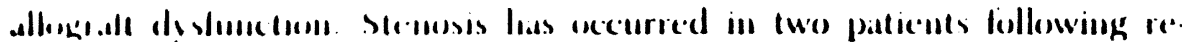

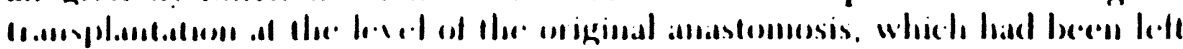

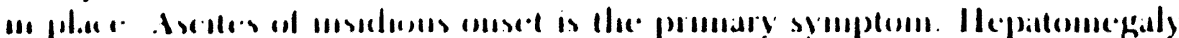

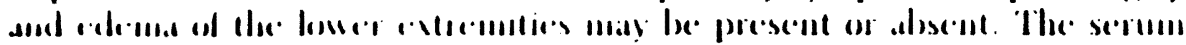

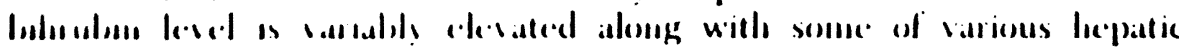

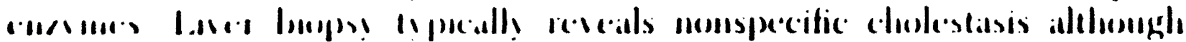

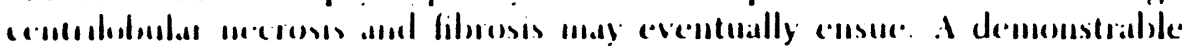

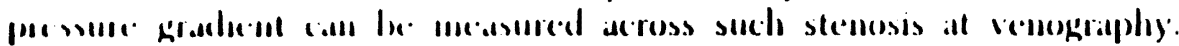

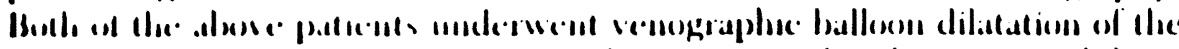

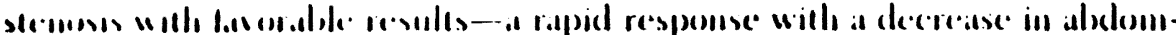

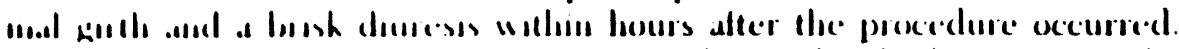

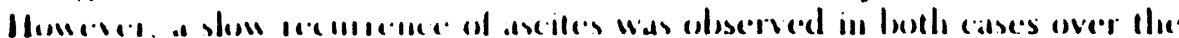

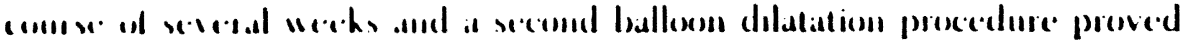

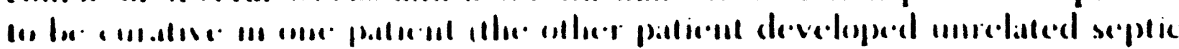

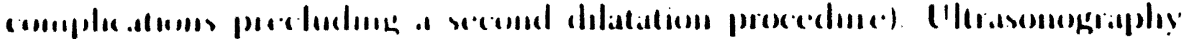

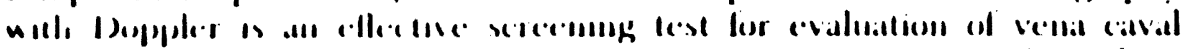

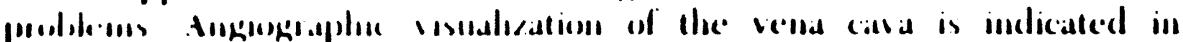
aloulullul a ases

\section{BII.IAKI COOMPLICATIONS}

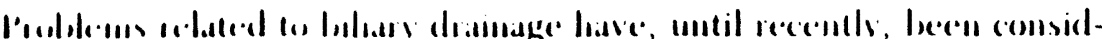

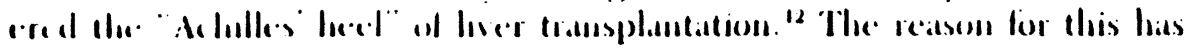

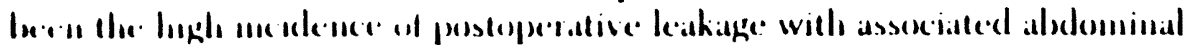

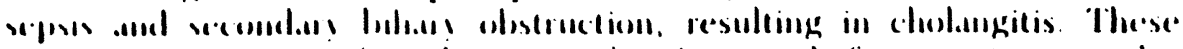

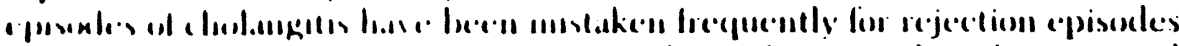

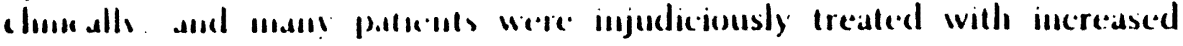

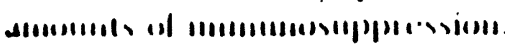

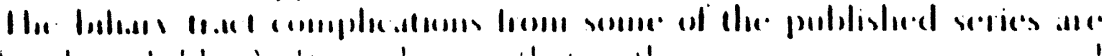

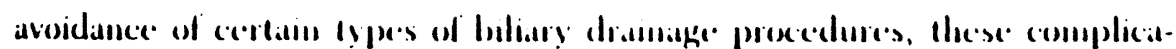

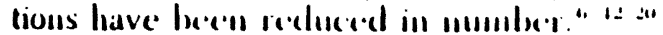

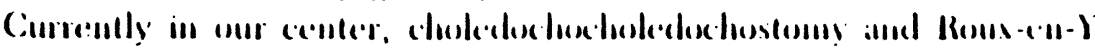

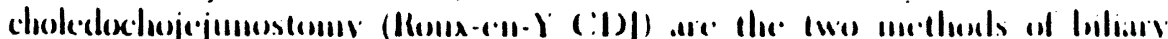

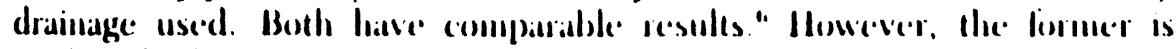
preferred whenevere leasible hecause it is quicker and provides access to

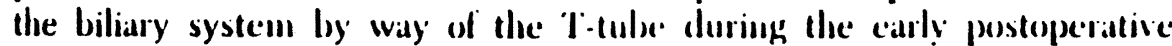
period (allows access (1) quantity and quality of hile and c.jolangiographlac studies) and by way of endoscopoic cholangiongraphy later.

\section{Bile Leak}

Relative Ischemia of the Dunor Bile Duct. It hass ber'll shown: Hhat at

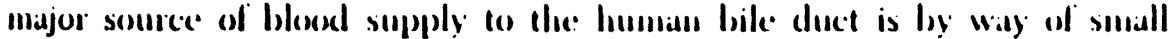

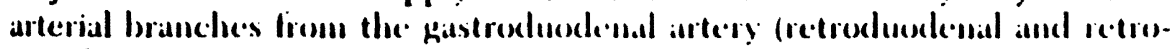

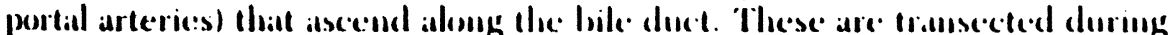

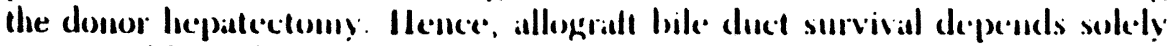
on arterial branchess that comere Irom the hilum of the livere. For this reaseme.

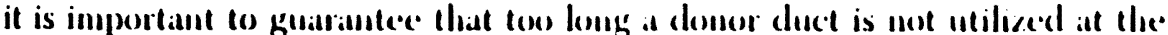
time of the biliary anastomosis. Allograti hepatic antery thrombesis renders

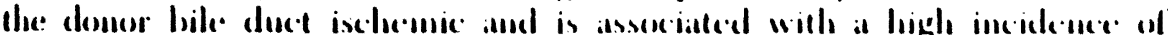
biliary leak, particularly if the thrombosis ocems within a lew days following trallsplanstiation.

Techuical fuctors. Tension at the andostemosis, excessite dissection around the recipients sommon duct injuring its bloud silpply, and placing l(x) many sulures of lathing lange bites and devitalizing lisste are somec of

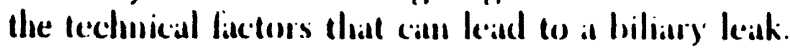

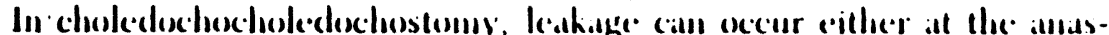

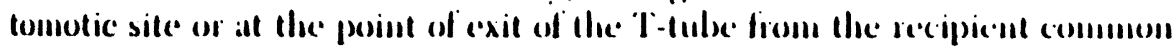
duct. Leaks around the T'tulse exit site are uot serious. If leaks atre small

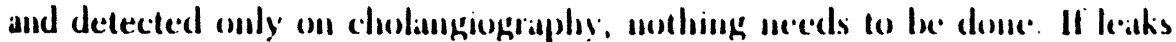

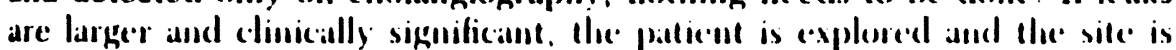

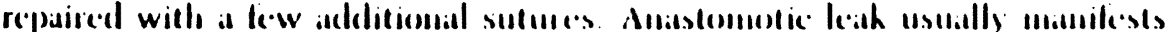

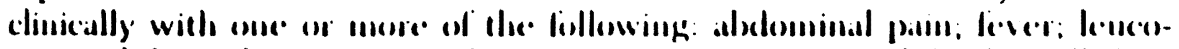

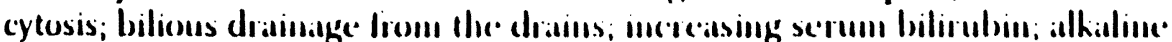

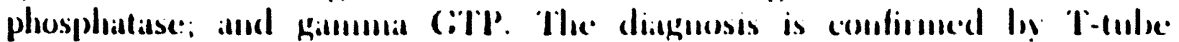

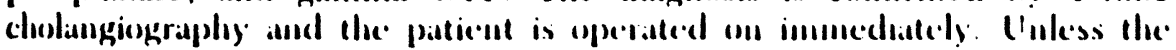

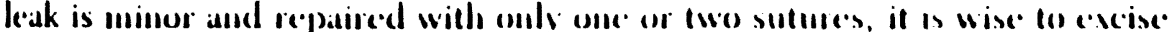

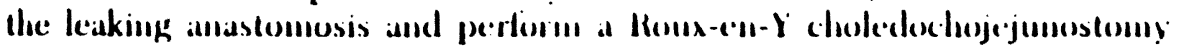
(Koux-en-I' ('I)]).

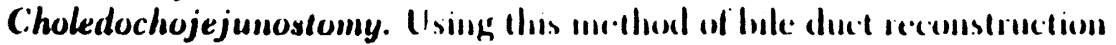
one does not have the laxiry of access to the biliary tre.e hy way of the Ttube. The diagnosis of a bile leak depends highly upon its clinical maniles-

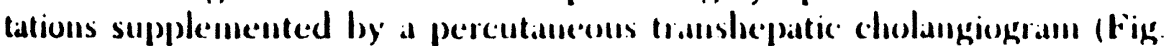
3). ()ecasionally the presence of very high hilirulsin levels in the drainathe

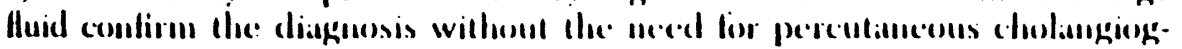
raphy. In most casses, hile leaks ance int the interior aspecet of the hilians-

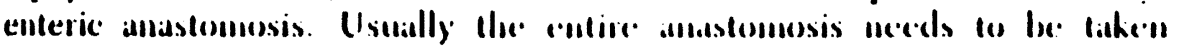

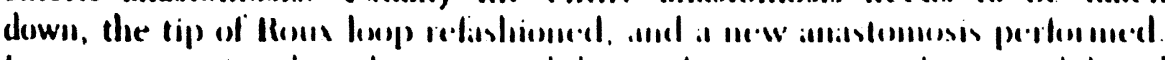




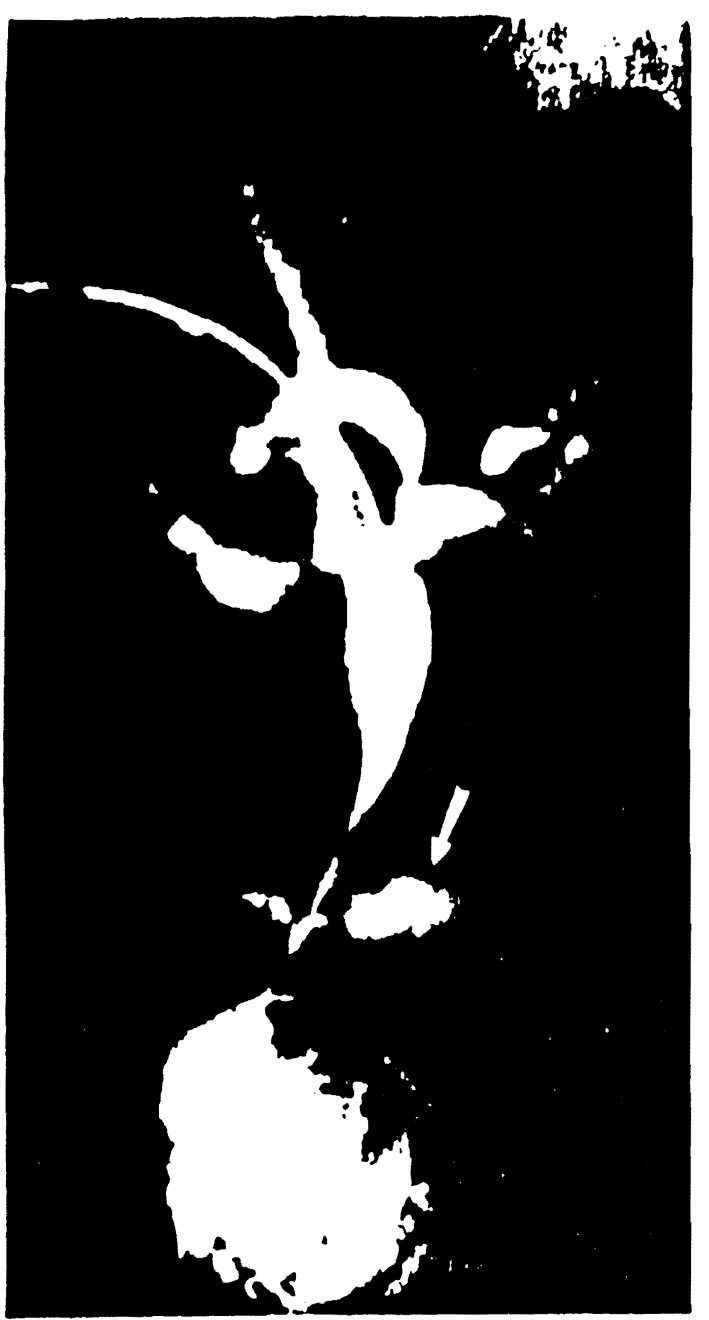

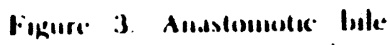

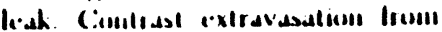

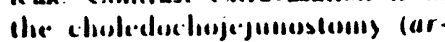

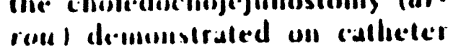

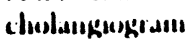

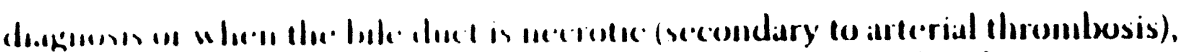

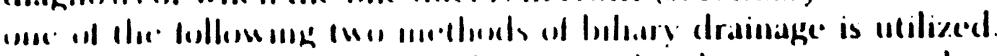

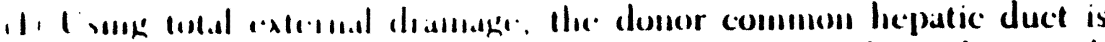

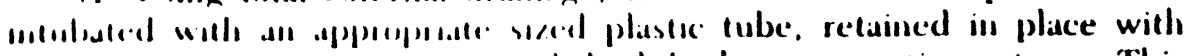

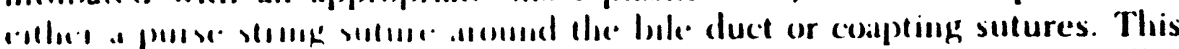

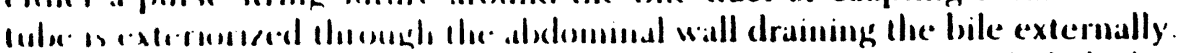

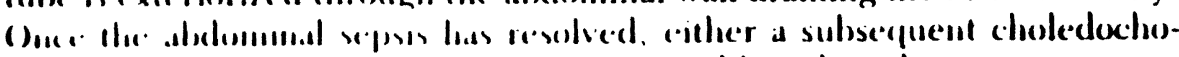

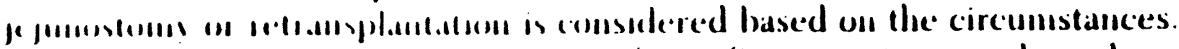

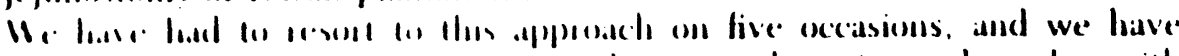

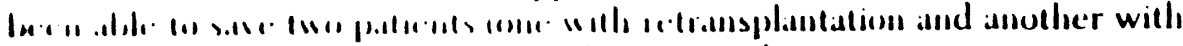

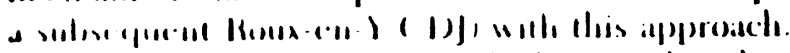

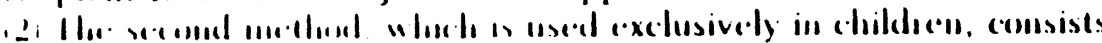

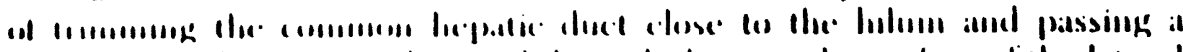

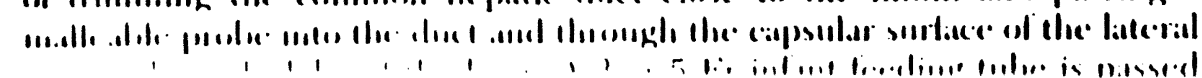

parenchyma over the malleable probe. $\lambda$ small opermug in the antimesen-

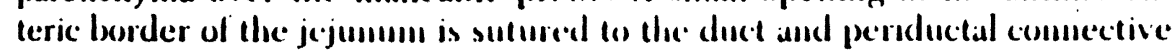
tissue after negotiating the leeding tulse into the jejunum.

\section{Biliary Obstruction}

The second major complication relited to the biliang tract occurs later in the postoperative course. The lactors that lend to pantial or complete biliary obstruction are similar to those that cause biliary leaks but ate lesser in degree. As with biliany leaks, increasing expertience and arosidance of certain biliary drainage procedures has reduced the prevalence of biliagy ubstruction.

Patients with biliary obstruction prescont as follows: (1) accute hacterial cholangitis with lever $\left(39-40^{\circ} \mathrm{C}\right)$, chills, aldominal pain, jaundice, and bacteremia with enteric orginisms: (2) relapsing eprisodes of mild lever $\left(38^{\circ} \mathrm{C}\right)$ and Huctuating liver injury paranneters; and (3) gradual deterioration

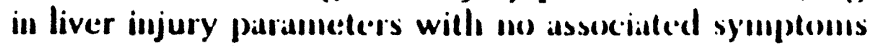

Fortunately Presentations 2 and 3 ance mone common than Presentation 1. With an insidiosus onset of olsstruction, Ihe perturbations produced in liver injury paranteters are frequently mistake'n fior all eppisode of rejection, hepatitis, and/or drug toxicity. Ilence it is important to have a high index of suspicion and to investigate such palticents in an organized manner with liver biopsy, serological tests for hepatitis, ultrasonography, and particularly' cholangiography. Ultrasonography is used as an initial screcening procedure. Unfortunately its false negalive ralte is quite high. In patients who still hatve

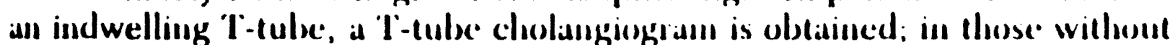
a T-tube, a percutancens transhepatic cholangiogram is olstained (Fig. 4)."

Based on the cholangiograplice linclingss. the problem is me of the following: (1) anl andastomostic nallrowing. (2) anl antastomotic and donor distal bile duct narrowing, (3) multiple intralleppatic strictures (usually ansocialted

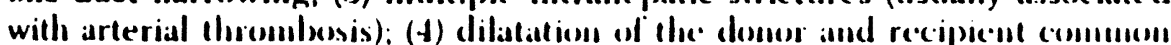

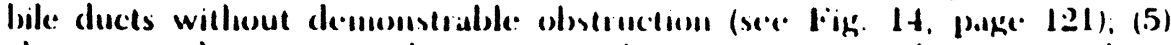

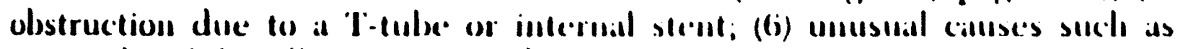
mucocele of the allogradt eystic dict (see l.ig. 12. patge 119) or recurrent

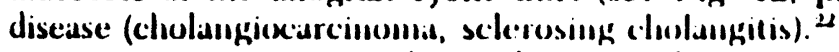

In recent years at the end of the dianguostic study, an inclucelling percutaneous biliary catheter has bee:n ledt in paticents with olistraction. This serves two purposes: it decounpresses the biliary tree and thereloy. lessens the urgency of the situation; and if surgical treatment is decided upon, the presence of the catlieter in the bile duct make's the approbath to the bile duct easier. Antibiotic coverage is recquired for the diaghuostic Ple: and cyclosporine dosage: readjustment after percutancous biliary draillage is accoumplished as mandatory.

Treatment. If the obstruction is lecalized, a trial of percutaneous

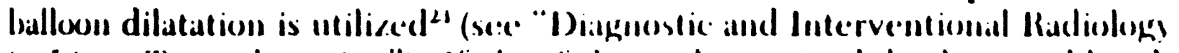

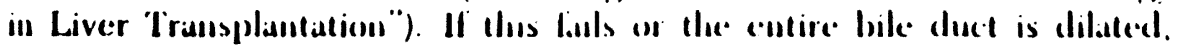

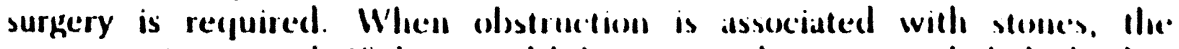

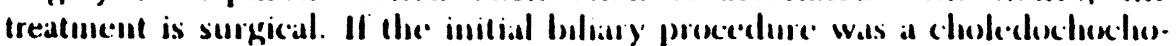

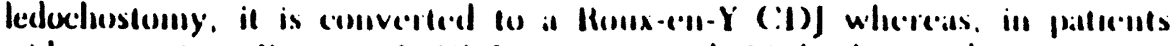

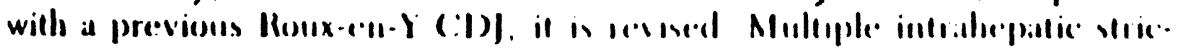




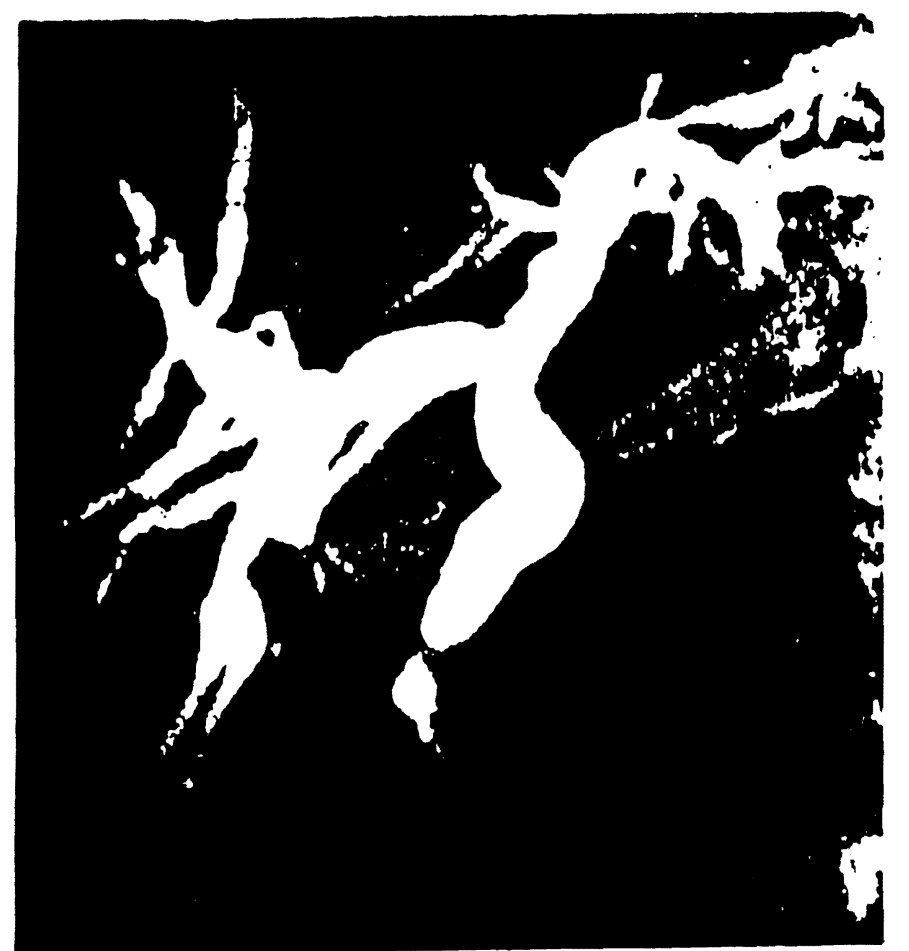

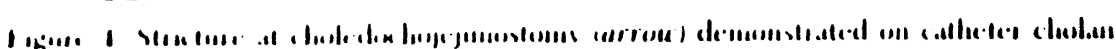

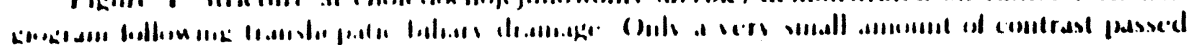

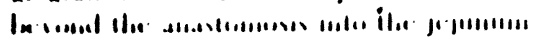

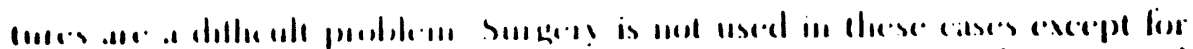

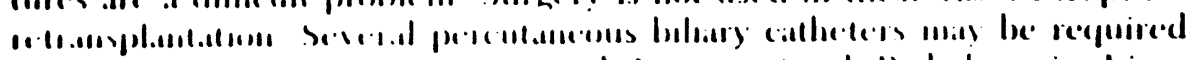

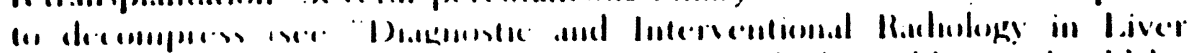

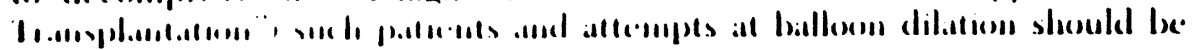

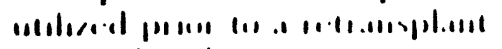

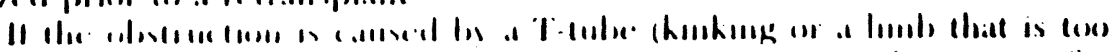

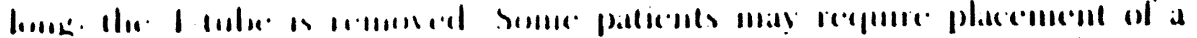

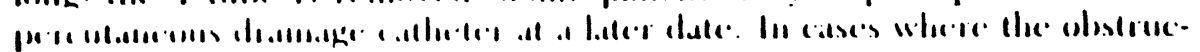

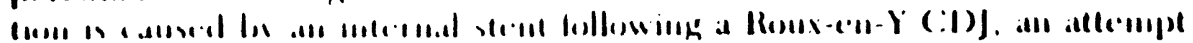

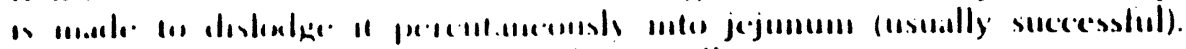

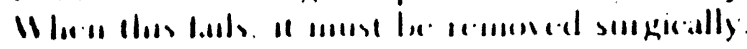

\section{IIIISIINAL COMPLICATIONS}

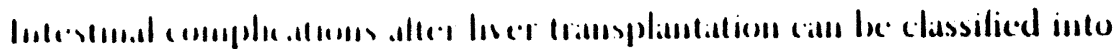

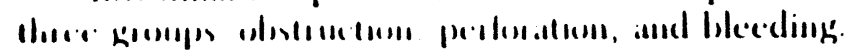

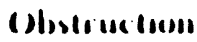

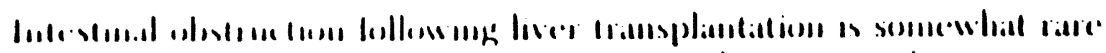

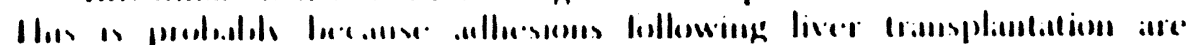

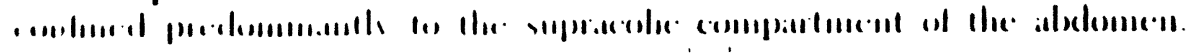

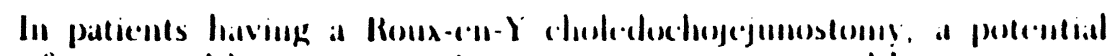

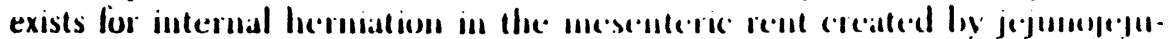

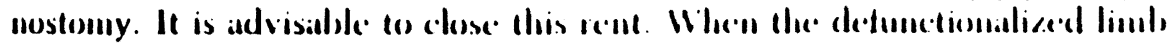

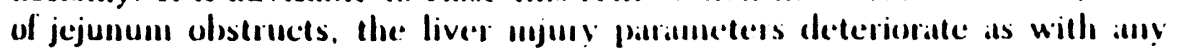

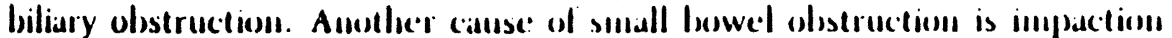
due to inspissation of aluminum antacids (Amplosjel, Alternagel). This rish

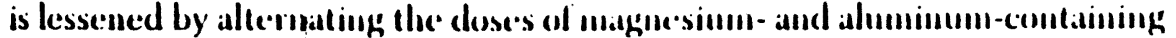
antacids. Lymphepproliterative disorders also have been shown to cause intestimal ubstruction. ${ }^{24}$

\section{Perforation}

This intestinal complication cant aceme either early or late. lianl!

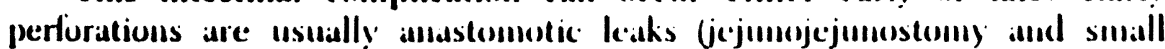
bowel resections) or perfioration of areas denuded of serosal or those injured by electrocautery. Diathermy is extensively used duriug liver tramsplant

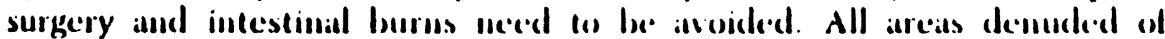

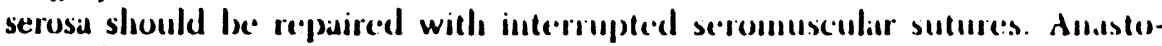
motic leaks ance more common in children. An intestimal leak shomld be suspected whenever there is cloudy drainage fiom the abdeminal drains,

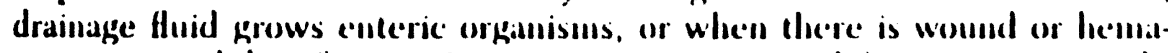
togenous candida inlection. Prompt reposir is essential for patient sirrival.

In patients having extensive adliesions at the time of transplant (especially children with several Kansili procedures), a routine "second lexh" exploration is pertiormed withion 3 los 5 dans. This alpprobach hats chalshed us to detect intestinal leaks and (1) deal with theme eflectively eally. In rate

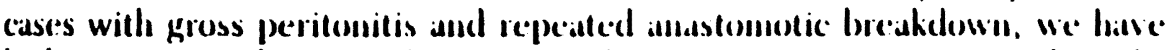

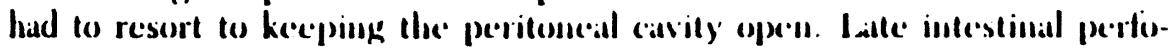
rations are excasionally the result of a ly mplenproblilerattive disorder."

\section{Bleeding}

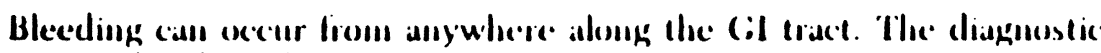

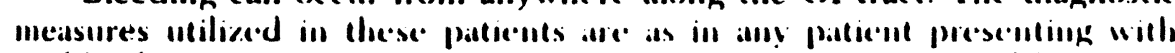

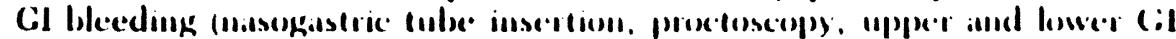

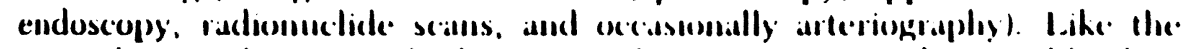

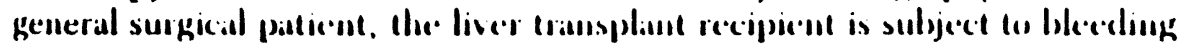

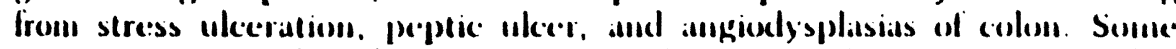
specilic causes of bleceding innportant in liver transplant patients are discussed.

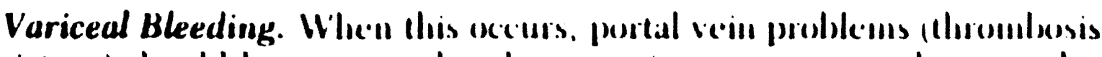
or stricture) should be suspected and approppriate tests pursued (see mincle.'

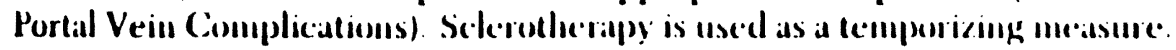

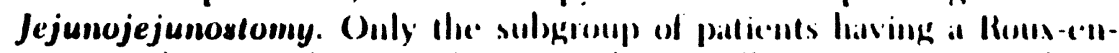
Y CDJ are subject to this complication. This usmally manilests towatid the end of the tirst postepserattive week, but oc(assionally call present 2 as 3

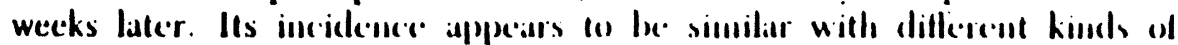

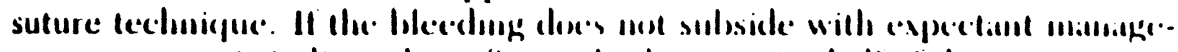

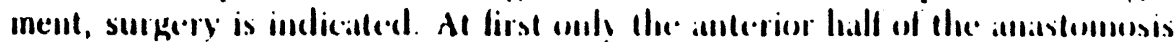

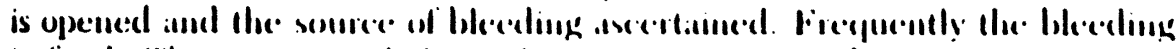

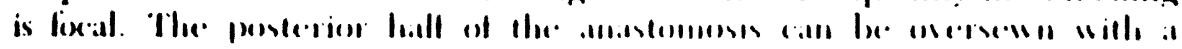




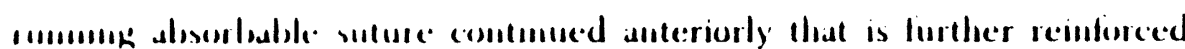

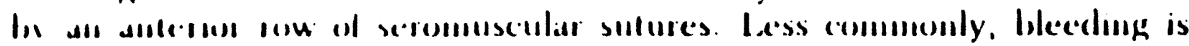

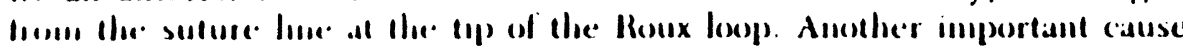

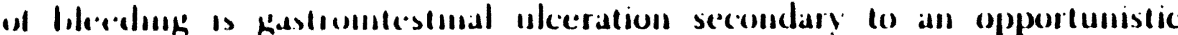

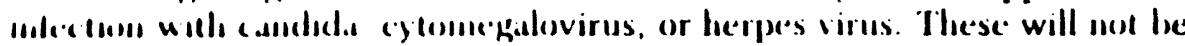
deall unlh in llus secthm. Sultice it to say that immunosuppression is either redeced on descontenned and the patient supported with translusions. Deaster inceasures of tedal colectomy or subtotal gastrectumy may be resorted

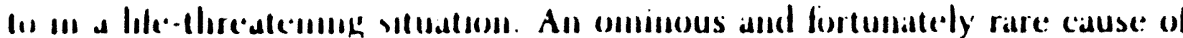

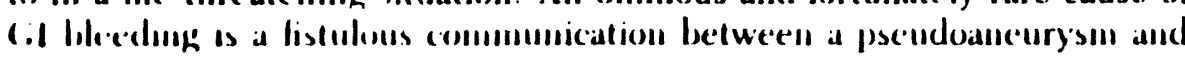
the intestince or bile. Anct. In a patient who presented with massive lower

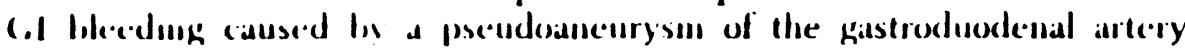

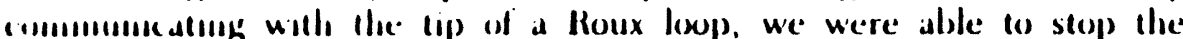

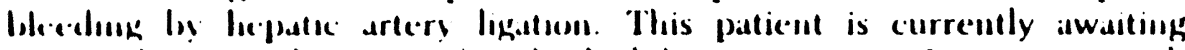

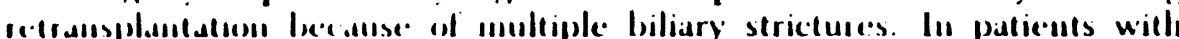

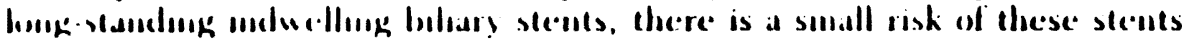

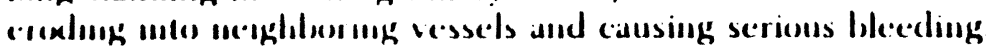

\section{ABDUMINAL INFECTIONS}

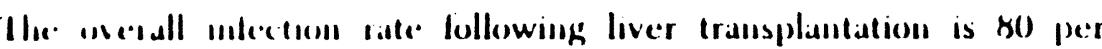
cand in linkectious complications account for most postoperative deaths.

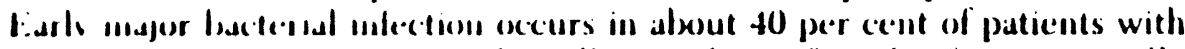

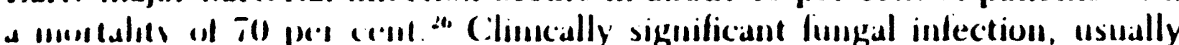

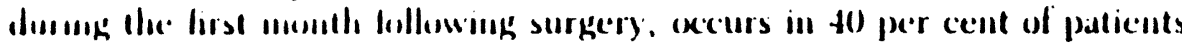

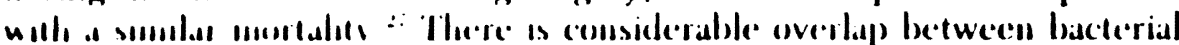

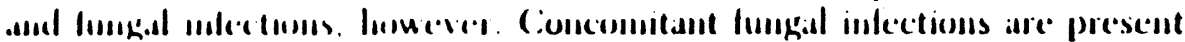

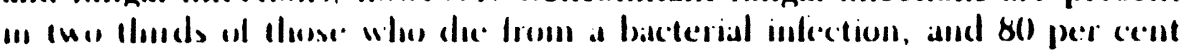

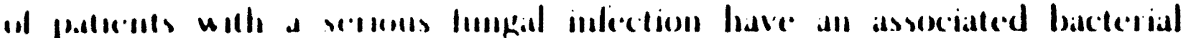

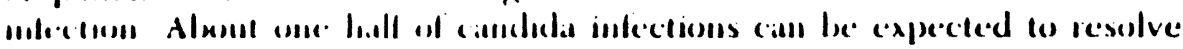

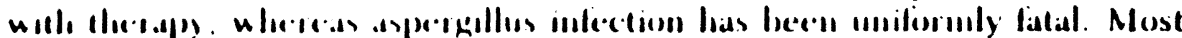

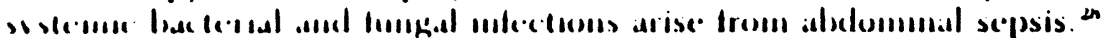

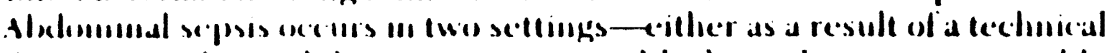

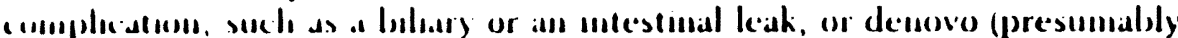

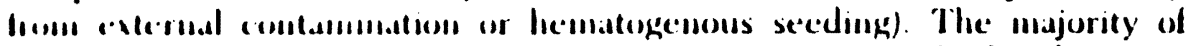

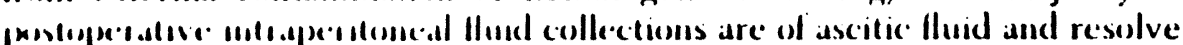

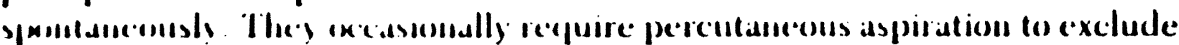
spon The incost commonn lexations ase in the hepatorenal and the left

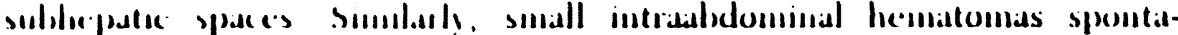

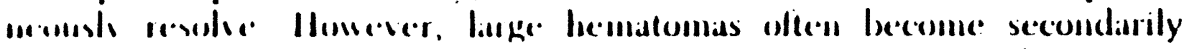

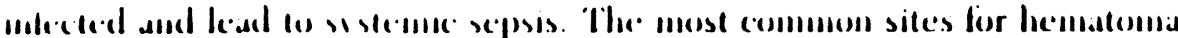

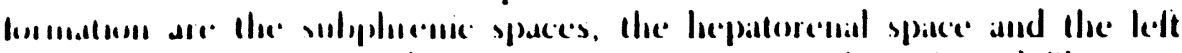

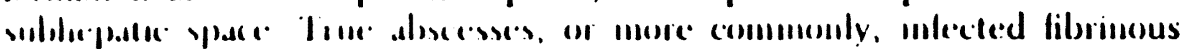

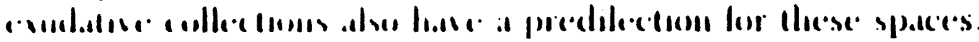

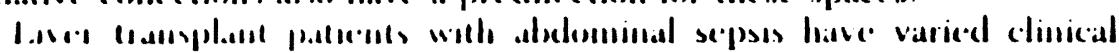

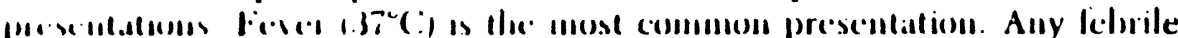

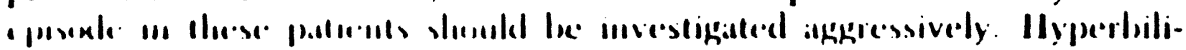

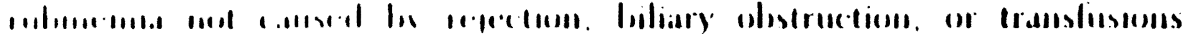

should also alert one to the possibility of sepsis. I.encocytosis is an unreliable. sign of sepsis, and hipootension and mential status changess ane later events.

Ultrasonography (US) and computerized tomographly (C:"1) are the key diagnostic tools. Each has limitations, and either one may be superior to the other in a given circumstance. The presence of ilens with gas-filled loops of bowel or an open aldominal womind limits the value of ultrasonography. Hemodynamice instability and a repuirement for hight positive end expiratory pressure (PEEP) makes transportation to a C"T monit unsale. A diagnostic laparotomy may be required in diflicult cases. The morbidity of a negative laparotomy is minimal, and one should not be hesitant to explore the patient if the suspicion of sepsis is strong and all other diangostic studies have been negative. Kadio-labelled lencexyte scans have been found to be unreliable.

The organisms usually responsible for sepsis in a liver transplant recipient are grant-megative centeric organisms. enterocoscus, or candidat. The presentece of yeast either in the aldedominal wound or in the draintage thuid should alert one to the possibility of either a visceral perforation or a biliary le:ak

Initially, broad-spectrum antiliontics are started whencever sepsis is considered likely. until culture and sensitivity reports are available (thirdgeneration cephalosporin and antipicillin or a new semisynthetic penicillin with an anmoghlycoside are good stanting choices). The prevailing bacteriological spectrum in a given hospital also dictates these choices. Antibiotics are only of temporary value, and the inlective source should be aggressively identified and drained. If one waits to see whether the patient improves, the tide often turns loward the long downhill path of inultiongan lailure and relfactory sepsis. It is innportant to rememember that infiected collections around vascular antastomoses arce assexiated with the danger of anl indastomotic rupture and fatal hemorrhagge.

In some patients, improvemene fiollowing drainage of a septec lixens in

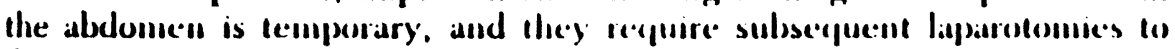

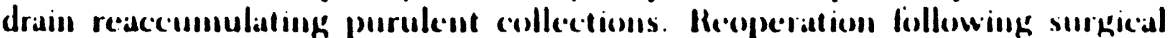

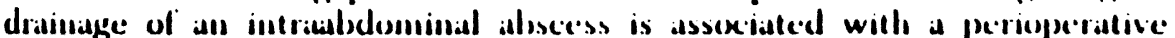
mortality rate of 30 to 50 per ceent. The This poor outcome has not iniproved despite advances in critical care support, noninvasive imaging, and the use of broad-spectrumn antibiotics. As a result, various modalities have becen advocated in the treatment of recurrent aldominal sepsis, some of which include a second-leov "scheduled" lapsanotoms, continuous peritomeal lavage, and leaving the abdumen open. sones Repeated laparotomies take the ir toll on the patient and often lead to further deterioration instead of improvement. As a result, one option occasionally utilized is leasing the abdominal cavity open following surgical drainatge and irrighation. Daily "laparotomices" and extensive irrigation of the abdeminal cavity are pere formed by the surgical stall using sterile technigue at the bedsicle int llee

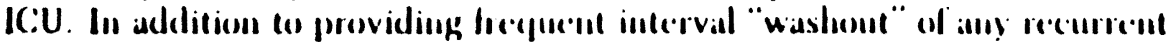
inlection, this method gives the surgeon an opportunity to inspect and examine the intrabledominal contents on a daily hasis. Disorders or commpli-

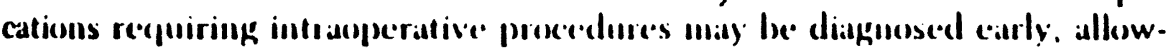

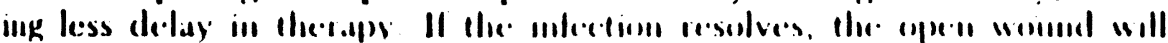




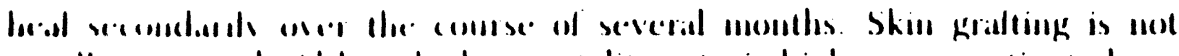

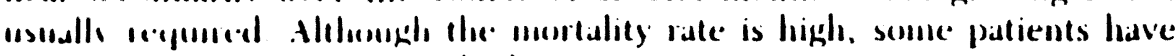

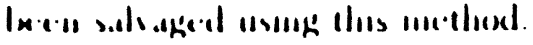

\section{WULND COMPLICATIONS}

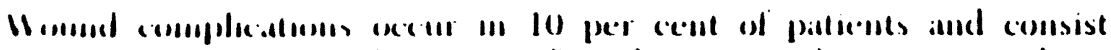

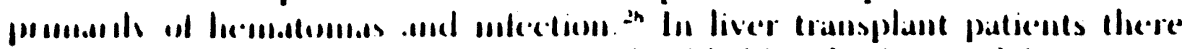

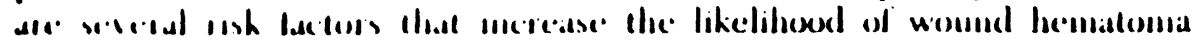

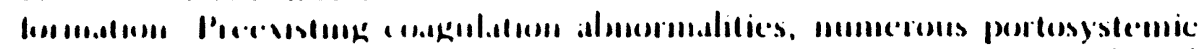

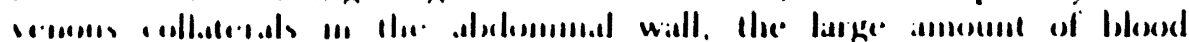

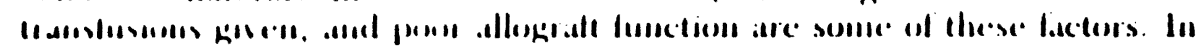

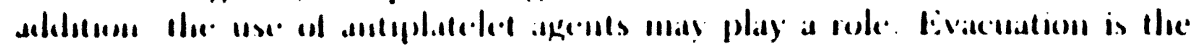

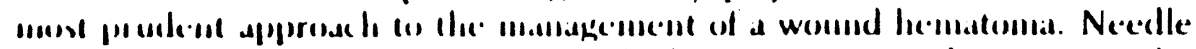

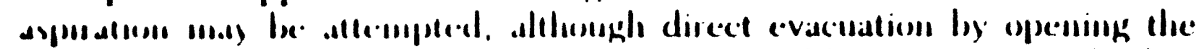

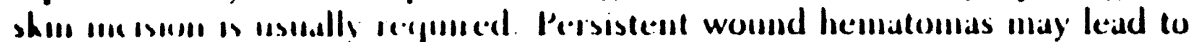

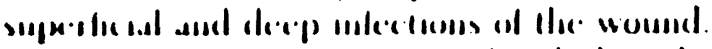

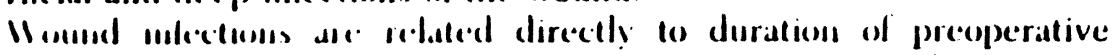

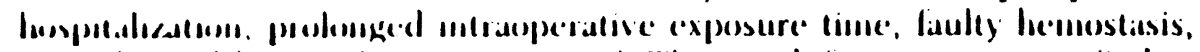

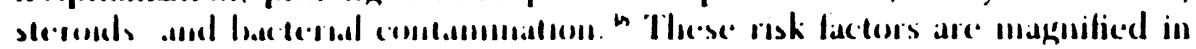

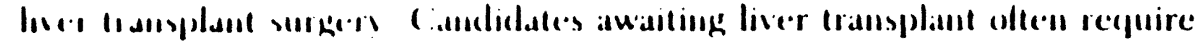

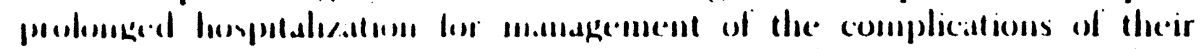

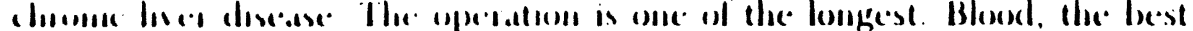

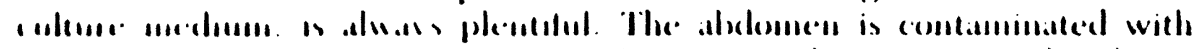

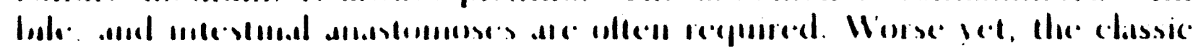

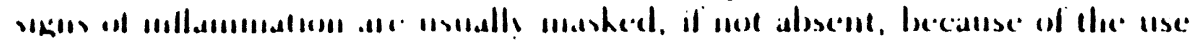

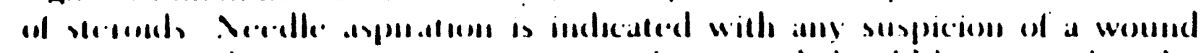

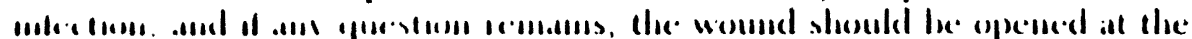

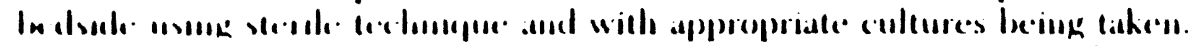

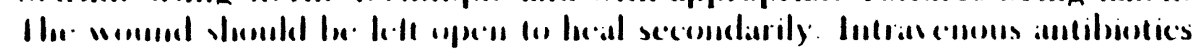

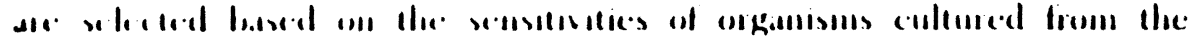

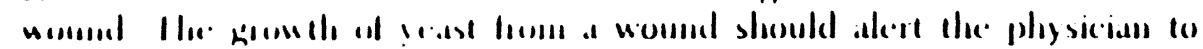

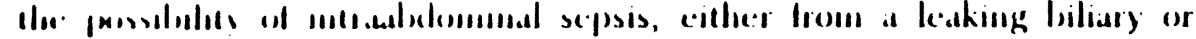

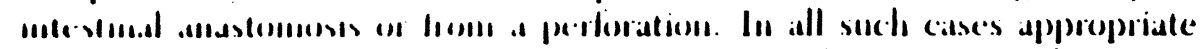

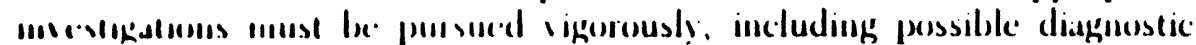

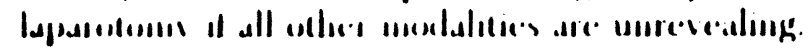

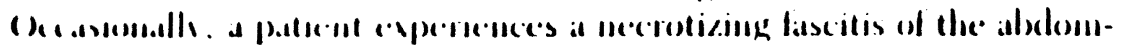

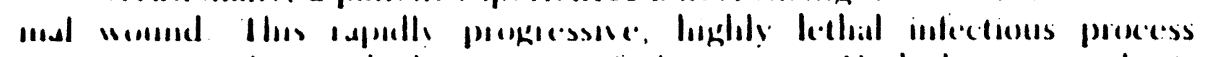

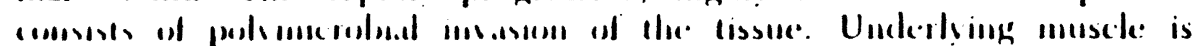

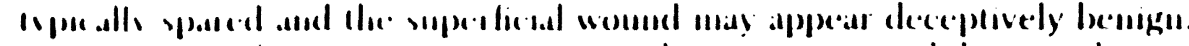

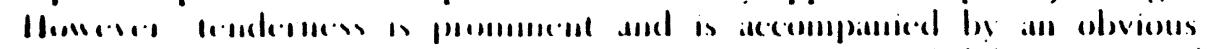

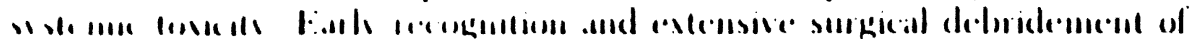

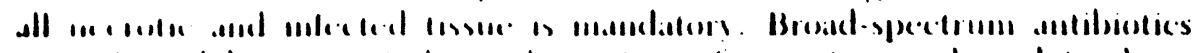

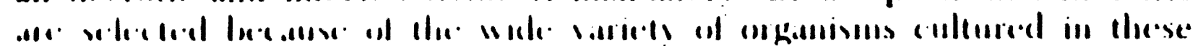

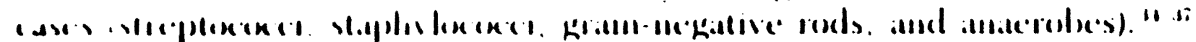

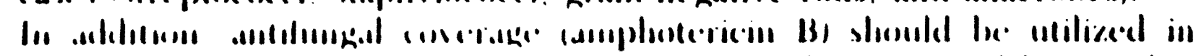

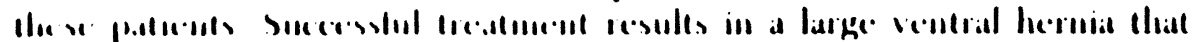

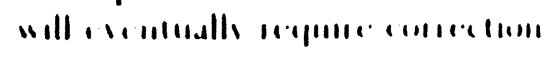

Occasionally the tension is tow great to approximale the lascial margins of the abdominal wound at the end of the transplant operation. The defect in the wound must then lee pottched with ant antilicial temporary cover such as Marlex or silastic. Tou lange a domor liver for a giveren recipient, prolonged clamping of the recipient portal ve.in, and an extremely probonged procedure are several of the factors responsible lon this situation. Postoperatively, the wound should be dressed with sterile hatlex at the bedside at least daily.

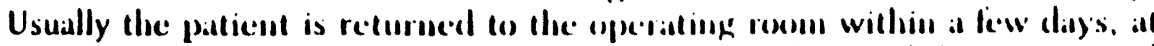
which time the abdomen is closed without difliculty. It definitive wound closure is delayed for more than a lew datys, the surgeou may encomiter considerable difliculty in attempting to spproximatle the wound mangins.

Axillany and groin incisions used for vernoverousus by pass are also subject

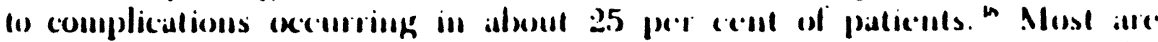

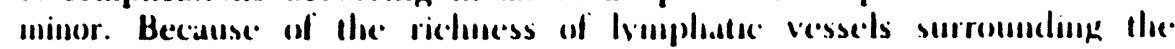
saphenous and asillany veins, lympheseles anc a comminom oceurrence. These resolve eventually, but maty recpuire periodic aspiration or even draintage. As these incisions are lexatted in intertriginoms areas and have prolonged operative expossures, superticial wound infection and breahdown is quite common. Upper and lower extremits edema can oxcur due to either asillany vein ligation or thrombosis and long saphenous vein ligation. A brachial plexus injury is rare but cant occur.

\section{COMPLICATIONS OF LIVEK BIOPSY}

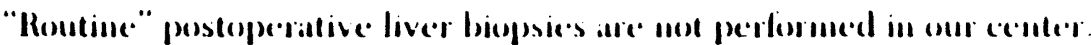

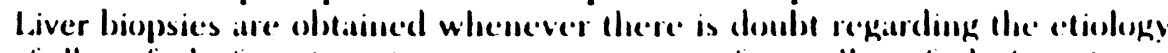
of allograft dystunction. Accurate assessme net of any allogralt dystumction is

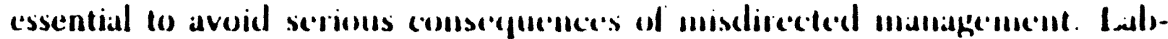

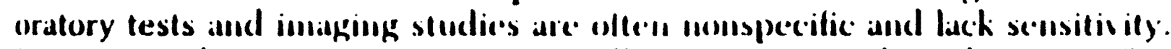
liver transplant patients recpuire ustailly one or more liver biopsites after surgery.

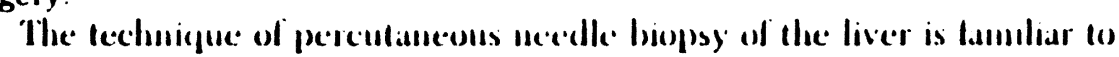

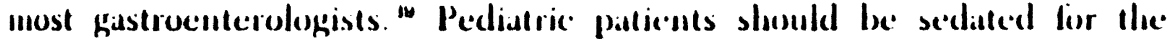
procedure. The hematex rit should be at least 25 per cent. Prior to the procedure, thrombocytopentia (platelet count less than 50,000) and coughlopathy (prothrombin time greater than 2(1)) alre corrected with translusions of platelets and fresh frozent plasmila. Righit-sided pulmonary discease, a pleural eflinsion, mechanical ventilation, and ascites are mot comsidered contraindications to liver biopsy in thansplant patients. The biopsy is performed using a Menghini tspe of needle through a midasillary intercostal alpproaclis

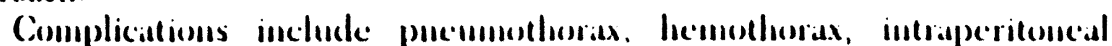

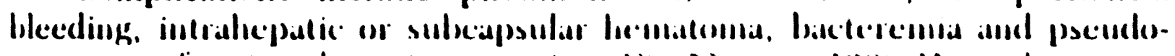

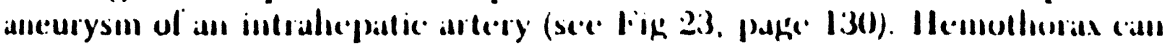

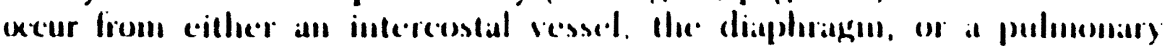

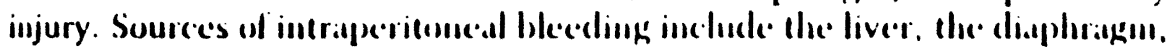

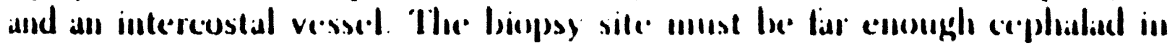

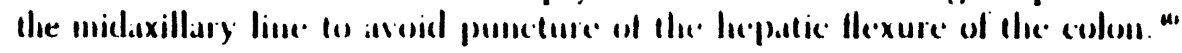




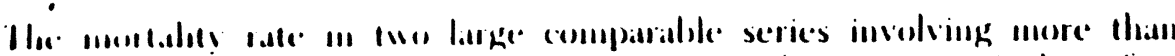

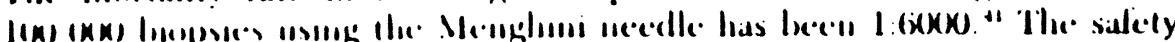

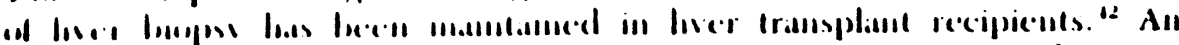

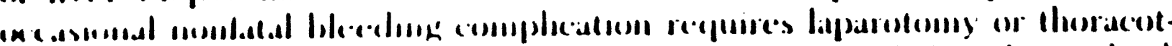

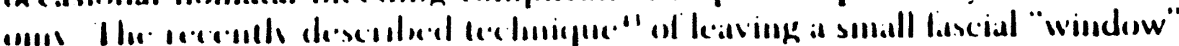

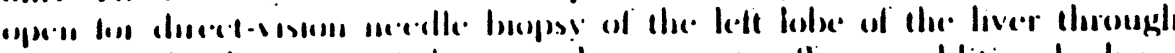

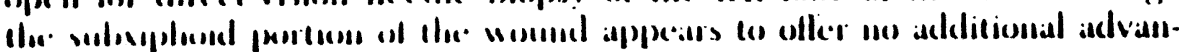

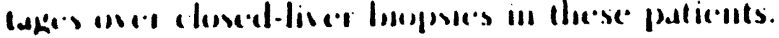

\section{PANC:REATITIS}

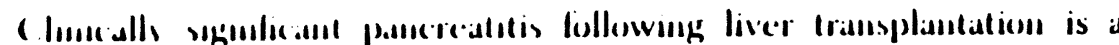

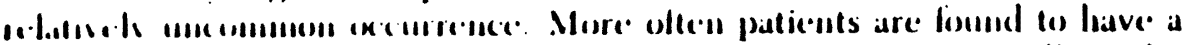

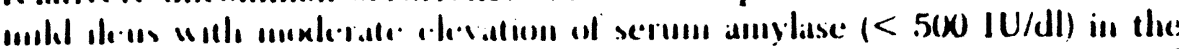

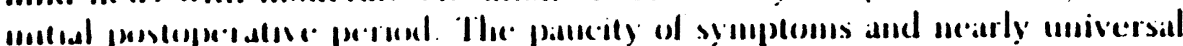

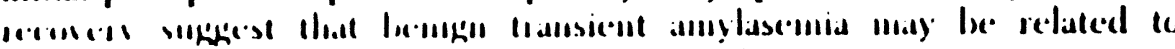

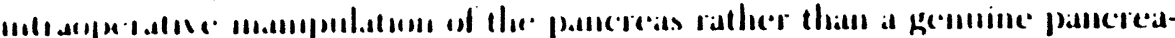

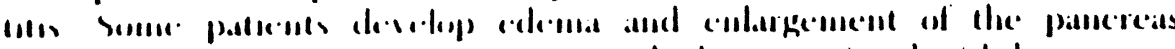

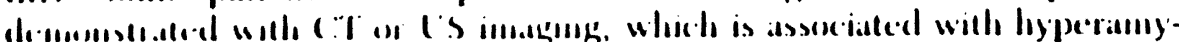

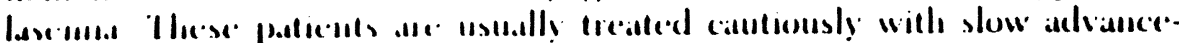

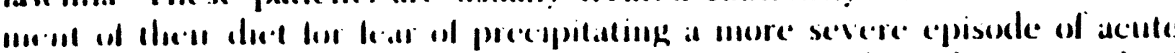

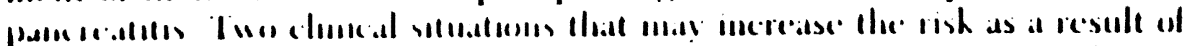

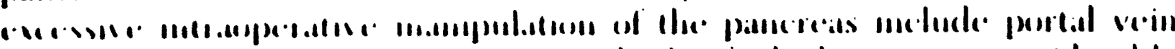

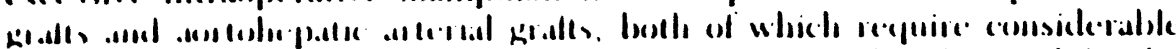

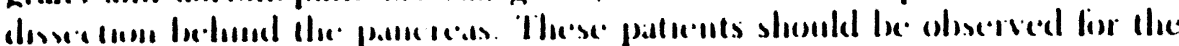

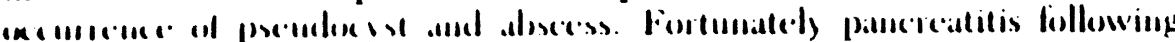

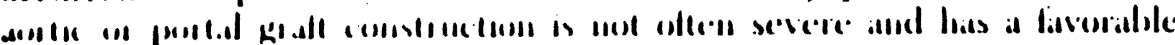

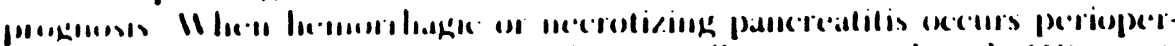

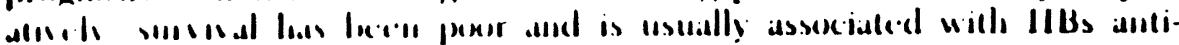
Li. … 1..1...

\section{SIIA:NIC COMPLICATIONS}

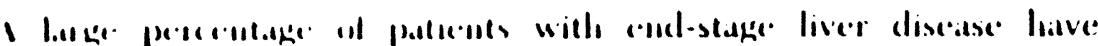

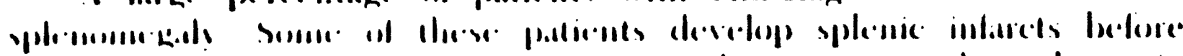

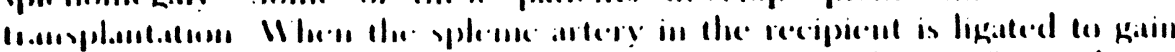

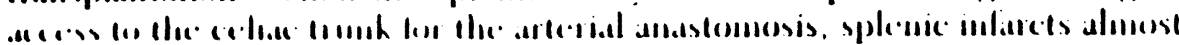

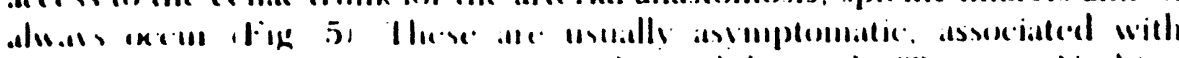

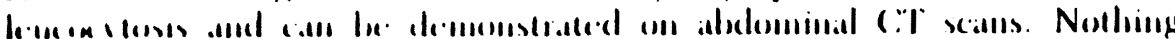

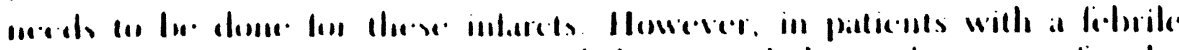

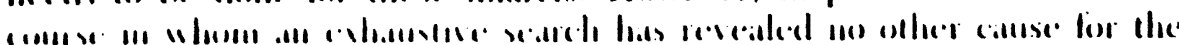

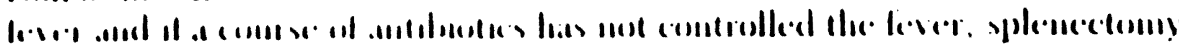

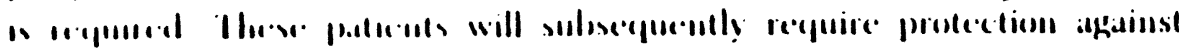

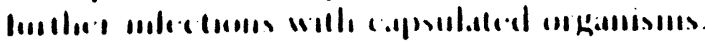

\section{(.lu) lous Ascilles}

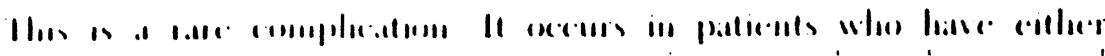

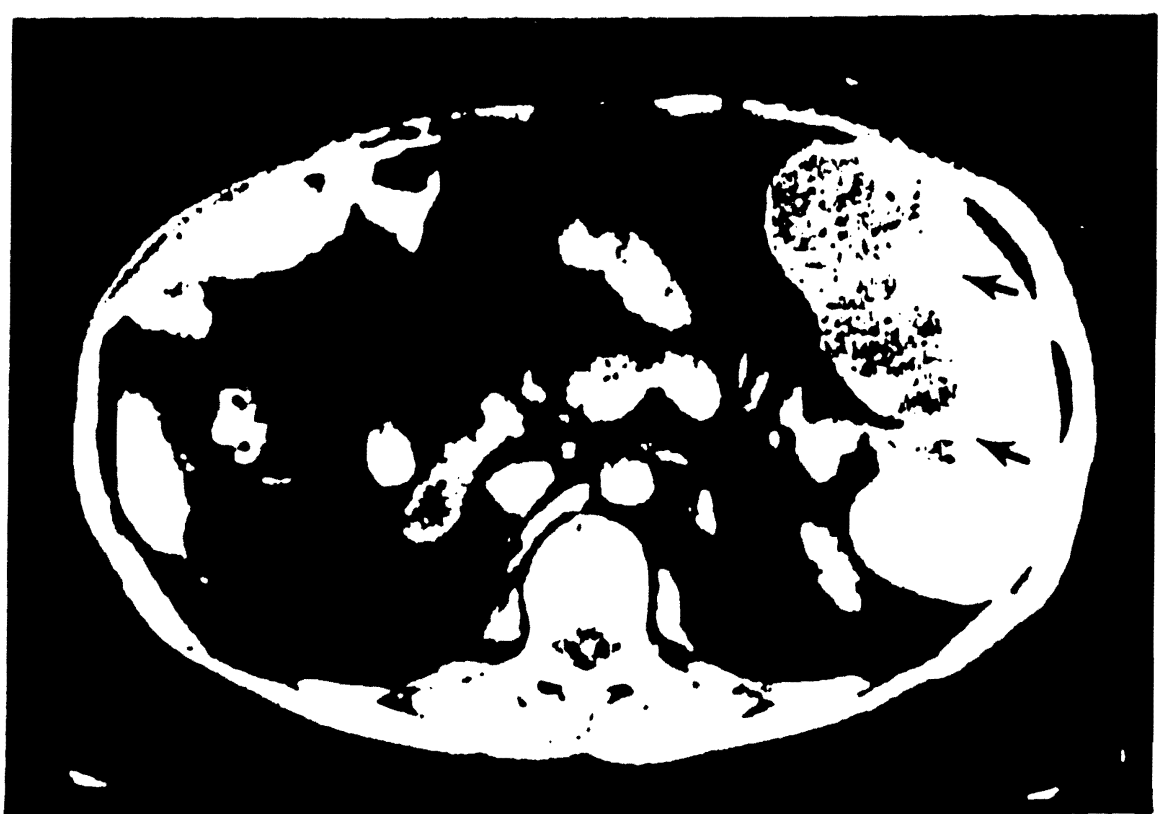

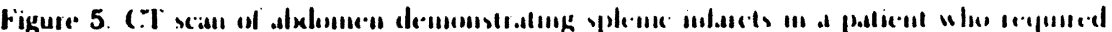

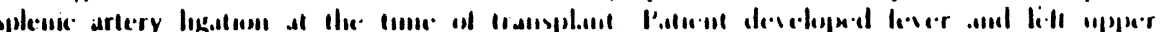

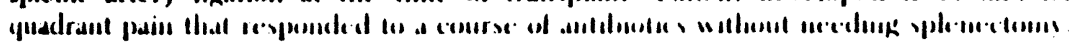

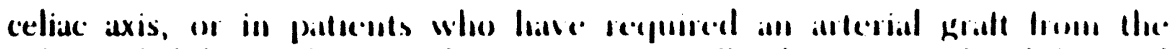

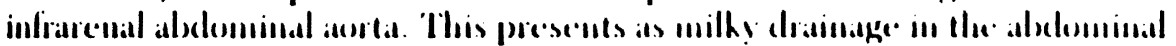

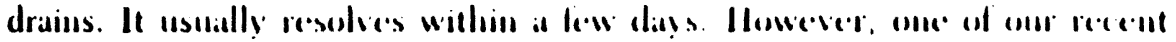

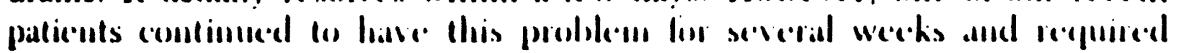

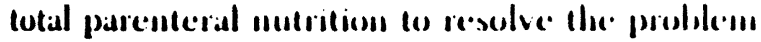

\section{RLFLRI:NCLS}

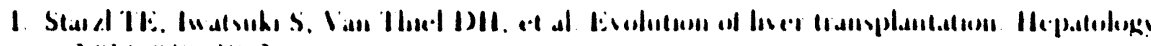
$2.61+-123), 1 ! \ln 2$

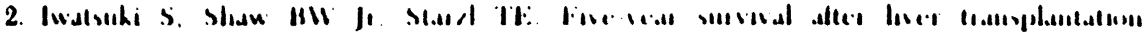

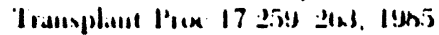

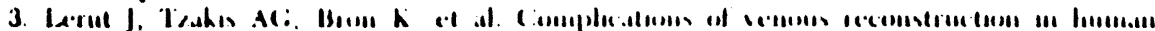

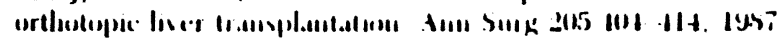

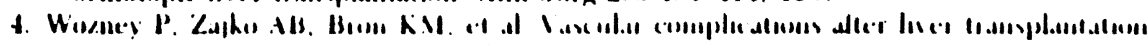

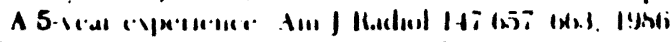

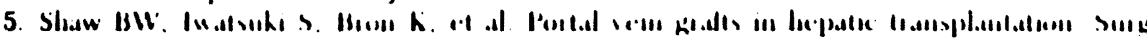

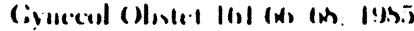

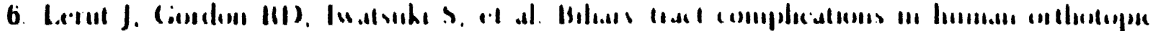

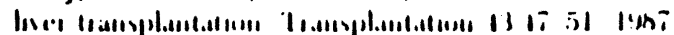

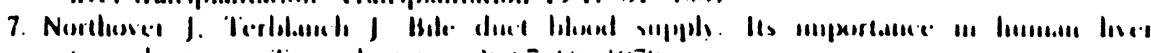

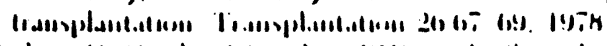

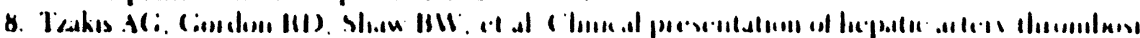

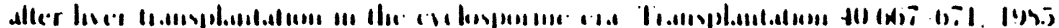

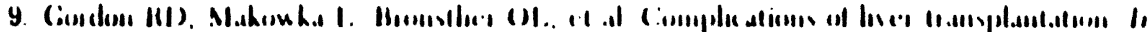

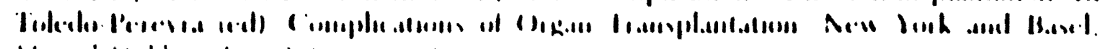


$101^{\circ} 3$.

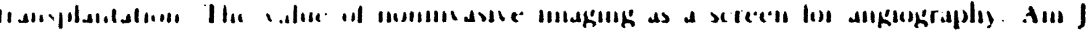

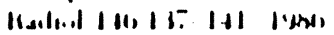

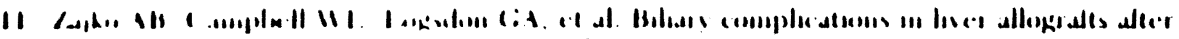

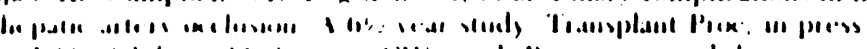

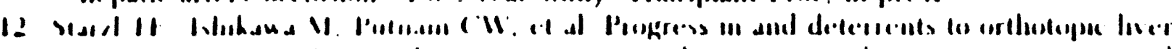

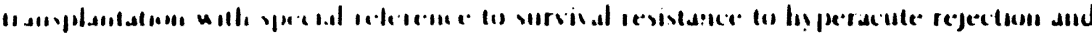

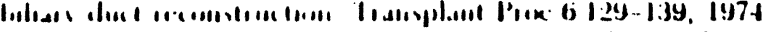

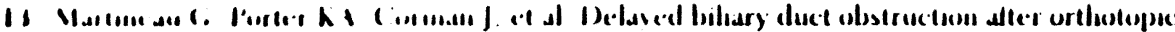

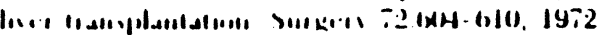

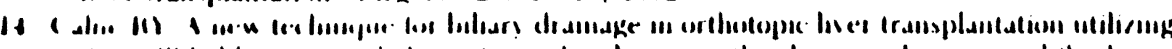

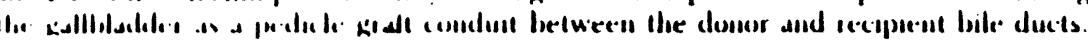

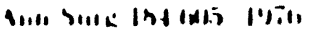

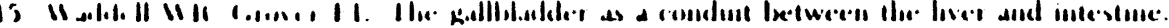

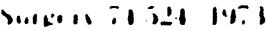

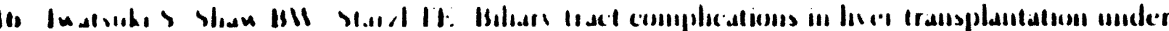

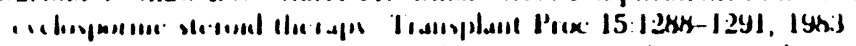

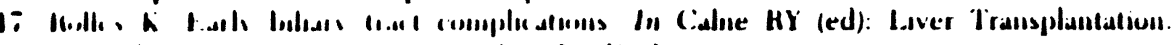

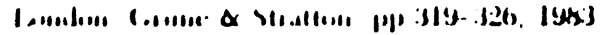

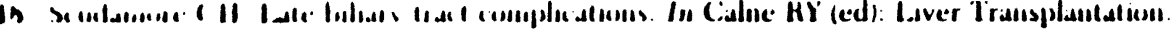

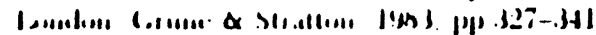

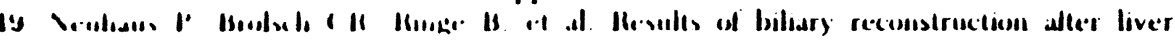

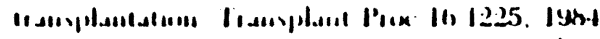

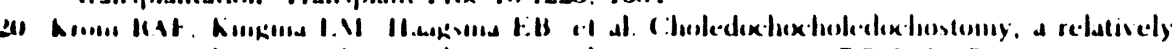

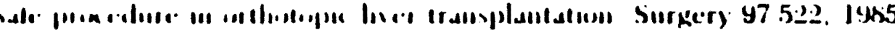

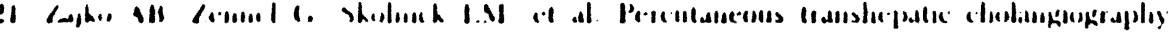

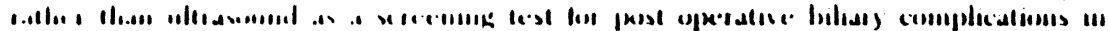

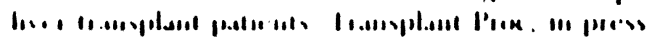

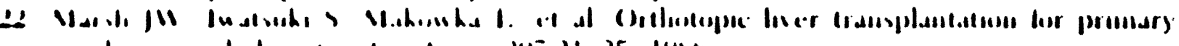

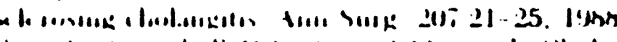

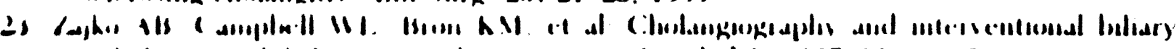

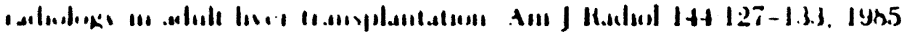

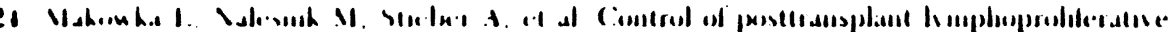

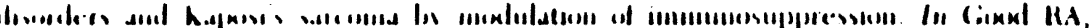

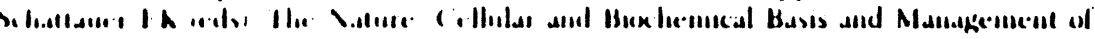

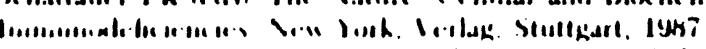

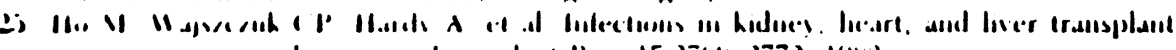

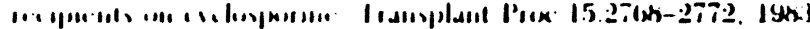

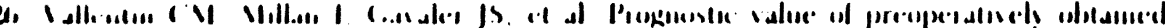

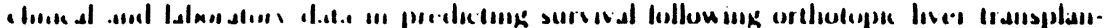

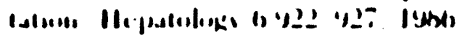

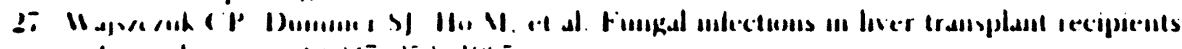

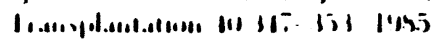

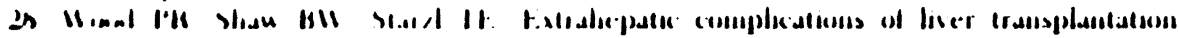

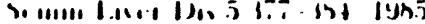

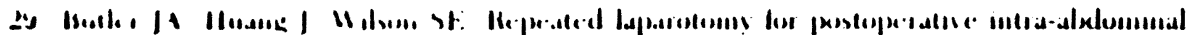

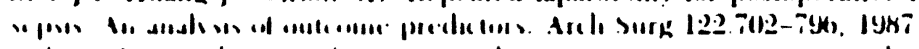

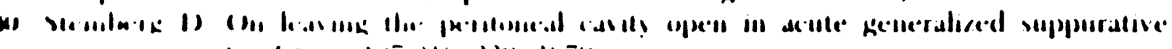

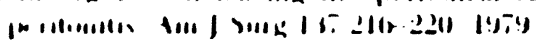

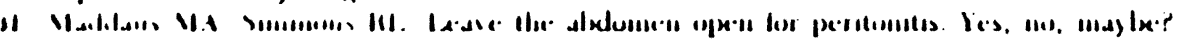
A.1. bing 21 I is lion:

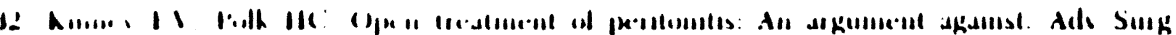

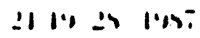

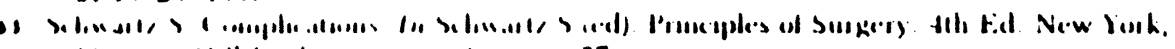

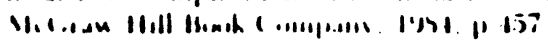

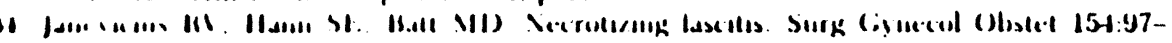
111! INL:

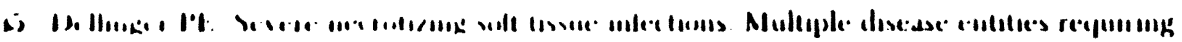

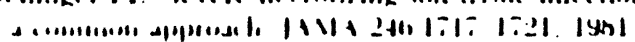

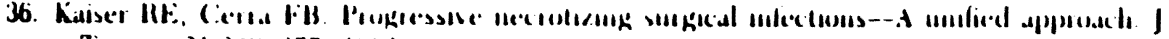

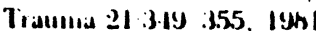

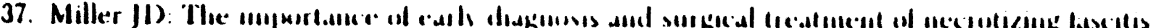

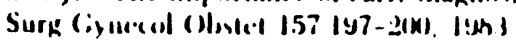

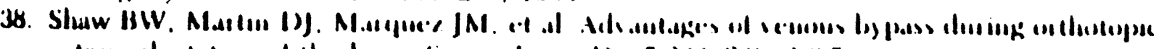

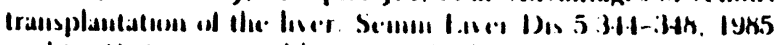

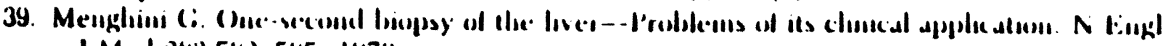
J Med 2803:5*2-5\%5. 1:971)

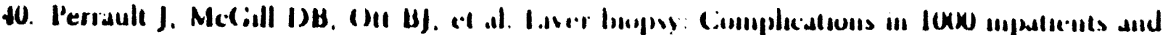

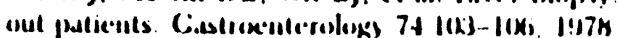

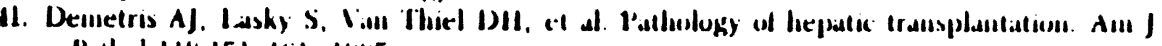
Palloul II8.151-16il. Isik5

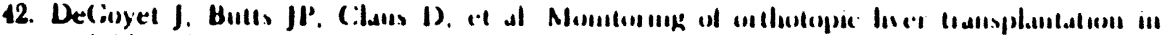

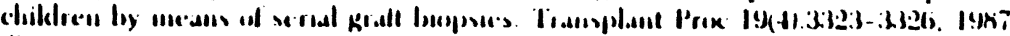

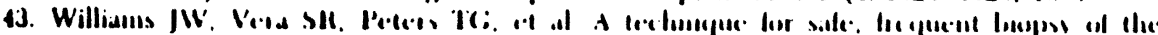

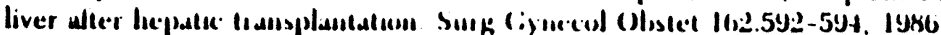

Department of Surgery

3601 Filth Avenue

Falk Clinic + IVest

Pittsburgh, Peninsylvania 15:1:3 